NBER WORKING PAPER SERIES

THE BARING CRISIS AND THE GREAT LATIN AMERICAN MELTDOWN OF THE 1890s

Kris James Mitchener

Marc D. Weidenmier

Working Paper 13403

http://www.nber.org/papers/w13403

\author{
NATIONAL BUREAU OF ECONOMIC RESEARCH \\ 1050 Massachusetts Avenue \\ Cambridge, MA 02138 \\ September 2007
}

We thank seminar and conference participants at UC Berkeley, the 2006 World Economic History Congress in Helsinki, and the UCLA Conference on States and Capital Markets in Historical Perspective for comments and suggestions. We also thank Nilisha Agrawal, Lydia Fung, Genna Tan, and Sean Hannley for research assistance, and Moritz Schularick for generously providing data. The National Science Foundation (NSF Grant 0518661) and Santa Clara University (Leavey Grant) provided financial support for this project. The views expressed herein are those of the author(s) and do not necessarily reflect the views of the National Bureau of Economic Research.

(C) 2007 by Kris James Mitchener and Marc D. Weidenmier. All rights reserved. Short sections of text, not to exceed two paragraphs, may be quoted without explicit permission provided that full credit, including $\odot$ notice, is given to the source. 
The Baring Crisis and the Great Latin American Meltdown of the 1890s

Kris James Mitchener and Marc D. Weidenmier

NBER Working Paper No. 13403

September 2007

JEL No. F34,F4,G15,N2

\begin{abstract}
$\underline{\text { ABSTRACT }}$
The Baring Crisis is the nineteenth century's most famous sovereign debt crisis. Few studies, however, have attempted to understand the extent to which the crisis mattered for countries other than Argentina and England. Using a new database consisting of more than 15,000 observations of weekly sovereign debt prices, we assess the extent to which the Barings Crisis affected other emerging market borrowers and find empirical evidence of a regional crisis. We find that Latin American yield spreads increased by more than 200 basis points during the crisis relative to the rest of the world, even after controlling for macroeconomic, trade, political-institutional factors, and other country-specific effects. Our evidence suggests that European investors may have sold off or reduced their holdings of Latin American securities in the wake of the Baring Crisis.
\end{abstract}

Kris James Mitchener

Department of Economics

Leavey School of Business

Santa Clara University

Santa Clara, CA 95053

and NBER

kmitchener@scu.edu

Marc D. Weidenmier

Department of Economics

Claremont McKenna College

Claremont, CA 91711

and NBER

marc_weidenmier@claremontmckenna.edu 


\section{The Baring Crisis and the Great Latin American Meltdown of the 1890s}

\section{Introduction}

The widespread occurrence of emerging market financial crises in the past two decades has sparked interest among economists and investors in understanding their nature, causes, and consequences. These episodes are often characterized by volatile capital flows, unsustainable or non-credible commitments to fixed exchange rates, currency mismatches, liquidity mismatches, and weak regulation and supervision of banking systems. Other studies have emphasized the role of contagion, the process through which a shock in one country can lead to a price movement in another country in excess of the underlying fundamentals (Forbes and Rigobon, 2002; Forbes and Claessens, 2001; Kaminsky, Reinhart, and Vegh, 2003). For example, some research has pointed to the role of asymmetric information, informed and uniformed investors, and political variables in the transmission of the Asian financial crisis (Calvo, 1999; Drazen, 1999; Hahm and Mishkin, 2000; Radelet and Sachs, 1998). Other studies have noted the importance of common creditors in propagating crises. To reduce overall portfolio risk, financial institutions in the common-creditor country (one with large holdings of emerging market debt) reduce and/or sell off their assets in the entire region, especially in countries that have characteristics similar to the crisis country (Kaminsky and Reinhart, 1998; Dornbusch, Park, and Claessens, 2000). The significant real-side effects of recent financial crises (Bordo, Eichengreen, Klingebiel, and Martinez-Peria, 2001; International Monetary Fund, 1998) has prompted some policymakers to call for a reform of the international financial architecture (Goldstein, 1998; Eichengreen, 1999).

To provide some historical insight into the global and regional effects of financial crisis, this paper turns back the clock and examines the most famous sovereign debt default of the nineteenth century - the Baring Crisis of $1890 .{ }^{1}$ The crisis originated in Argentina, and was then

\footnotetext{
${ }^{1}$ For related discussion on this point, see Mauro, Sussman, and Yafeh (2002), which examines monthly sovereign yield spreads over the entire gold standard period for 16 emerging market countries and Bordo
} 
transmitted back to London via the House of Baring (an investment bank in London that held large amounts of Argentine debt that could not be placed in the London market). ${ }^{2}$ Most previous studies have examined the effect of the crisis on Argentina or the Bank of England's rescue operation of the House of Baring. We break new ground by thoroughly examining the global effects of the Baring Crisis on a sample of 41 emerging market borrowers. Using a new database of over 15,000 weekly sovereign debt prices collected from the Economist, the empirical analysis of sovereign yield spreads suggests that the Baring Crisis was primarily a regional crisis. The country risk premium for Latin American countries increased by more than 840 basis points between 1890 and 1891, and more than 1,600 basis points between 1890 and 1895 . In contrast, yield spreads for non-Latin emerging markets and "core" countries (high income European countries and the U.S.) were generally flat or unchanged during this period.

We next construct a panel data set consisting of annual data for 35 sovereign borrowers, which includes macroeconomic indicators, trade variables, political and institutional factors, and other country-specific controls. The results from the fixed-effect regressions suggest that bond yields in Latin-American countries were more than 200 basis points higher as a direct result of the Baring Crisis - even after we control for macroeconomic fundamentals (such as its debt burden, budget deficit, and trade balance) and other country-specific effects (including gold-standard membership and whether it was involved in a conflict). This finding is consistent with the literature on modern crises and contagion that emphasizes their regional nature (Glick and Rose, 1999; Calvo and Reinhart, 1996). We also find some evidence that the crisis may have spread through trade. Finally, we discuss why European investors may have sold off or reduced their holdings of Latin American securities in the wake of the Baring Crisis

and Eichengreen (1999), which provides a chronology of banking and currency crises between 1870 and 1973.

${ }^{2}$ For examples, see della Paolera and Taylor (2001), Eichengreen (1999), Ford (1956, 1962), and Williams (1920). 
In the next section, we provide some historical background on the crisis. Section III describes our new database of sovereign debt prices, calculates spreads, and presents graphical and summary evidence regarding the effects of the crisis on emerging market borrowers. Section IV then examines the evidence concerning the regional nature of the Barings crisis using our annual panel dataset. The last section offers some concluding comments about the global nature of the crisis.

\section{The Baring Crisis of 1890}

The world debt crisis of 1873 and the ensuing recession had large economic effects on Argentina and Latin America. The region did not recover from the downturn until the early 1880 s - after the resolution to wars with indigenous peoples living in the pampas in the late 1870s. With the election of the war hero, Julio Roca, as president, Argentina witnessed a resurgence of foreign trade and capital flows from Europe. The funds were used to construct railroads and public works and modernize Buenos Ayres (Marichal, 1989). Roca's first major loan was a railway issue that completed two major trunk lines. The construction of a transportation network throughout the country further consolidated the central government's power and stimulated economic activity by opening up the market for commercial agriculture. Roca also transformed Buenos Ayres into the "Paris of South America" by constructing broad avenues, spacious parks, a well-functioning water supply and drainage system, and a modern port. Between 1880 and 1886, the national authorities and the government of the province of Buenos Ayres carried out a series of unprecedented state-run development projects in Latin America (Marichal, 1989).

As a result of the open capital markets that prevailed in the nineteenth century, Argentina was able to borrow extensively abroad. It was the fifth largest sovereign borrower in the world. It absorbed roughly 11 percent of all new issues in the new London market between 1884 and 1890 and 40 to 50 percent of all lending that occurred outside the United Kingdom in 1889. (In contrast, North America had a population 20 times Argentina's and floated only 30 percent of the 
new issues in London.) $)^{3}$ Taylor (2003, p.177) suggests that "the 1880 s stand out as a period of totally unprecedented capital inflows into an emerging market at any time in history." The current account deficit, as a percent of GDP, averaged 20 percent from 1884 to 1889 .

Although the economic policies of the 1880 s stimulated short-run economic activity in Argentina, they posed potentially serious long-run financing challenges. The financing of railroads and land improvement projects were aimed at promoting internal development, exports, and economic growth. But the slow maturation of the development projects could impede the country's ability to service its debts creating a maturity mismatch problem. The expanding national debt could only be serviced if the country had sufficient tax revenues for debt service. Unfortunately, it would take years before the government would realize significant revenues from commercial activity stimulated by the infrastructure investments (Ford, 1956). In addition, Argentina issued bonds in sterling or gold on European capital markets while the country operated on a paper standard (following several failed attempts in the early-to-mid 1880s to adopt a gold or bimetallic standard). The currency mismatch problem meant that a depreciation of the paper peso could impair the country's ability to service its gold debts (della Paolera and Taylor, 2001).

When the brother-in-law of President Roca, Miguel Celman, succeeded him as president of Argentina in 1886 in a fraudulent election, the newly elected leader sold the Central Norte and Andino railways (two of the country's most important railways) to British capitalists with the intention of reducing the country's rising debt level. Even though the government stopped borrowing funds to finance new railway projects, it did not restore fiscal discipline; instead, it began issuing additional debt through state banks. From 1886 to 1890, Argentina passed a series of "banking reforms" that fueled the expansion of credit and paper money issues (Williams, 1920). National and Provincial Banking authorities ratified a Free Banking Law in 1887 which authorized any banking association to issue notes provided that it purchased gold bonds to the full

\footnotetext{
${ }^{3}$ della Paolera and Taylor (2001, p.53) and Eichengreen (1999).
} 
amount of the notes issued. As noted by della Paolera and Taylor (2001), there were several problems with the law even though it was modeled along the lines of what was used in the U.S. under the National Banking Acts. The Argentine permitted banks meeting minimum capital requirements to issue paper notes backed by government gold bonds. The bank notes, however, were not redeemable in gold, and since the gold bonds were new issues, they constituted a new liability on the government's balance sheet. The banks that participated in the note issuance scheme floated loans in Europe to finance the purchase of the domestic gold bonds that backed note issuance. This scheme worked as long as foreign investors agreed to purchase the Argentine bonds and as long as additional note issuances were backed 100 percent by specie. Foreign investors, however, essentially were backing a credit boom in Argentina, financed by the issuance of new paper currency. ${ }^{4}$ By 1890, Argentine provincial banks had issued more than 30 million pounds of debt on foreign capital markets.

Beginning in the mid-1880s, loose monetary and fiscal policies substantially worsened macroeconomic conditions in Argentina. The monetary base grew at an annual average rate of 18 percent (driven by the issuance of paper currency emissions), inflation averaged 17 percent, and the paper peso depreciated at an average rate of 19 percent between 1884 and 1890 (della Paolera and Taylor, 2001, p.80). Argentina was also running a substantial budget deficit. The Argentine economy worsened towards the end of the decade, with as much as 40 percent of foreign borrowing going towards debt service and 60 percent of imports going towards the purchase of (non-investment) consumption goods. Railway net profits were declining and gold pesos were trading at a large premium (94 percent) relative to paper pesos (Fishlow, 1989, p.88). The former finance minister Jose Terry suggested that, "until the end of 1887, it was possible to save the patient: in 1888 , it already was no longer possible."

\footnotetext{
${ }^{4}$ For a detailed discussion, see della Paolera and Taylor (2001).

${ }^{5}$ Quoted in Fishlow (1989, p.88).
} 
By the end of the decade, it was becoming clear to the financial community that paper pesos were inadequate to cover the normal service on the internal and external debt. In 1889, the government broke its promise and paid off some of its gold-denominated liabilities with paper currency. In response, primary issues on the London market were met with a tepid response, and investors dumped paper pesos in anticipation of a further decline in its value. The government used the gold (that backed the note issues) to defend the exchange rate, but by December 1889, the stock of gold at the Banco Nacional had dwindled such that it could no longer carry out this intervention in the currency market. Strikes, demonstrations, and a failed coup by military leaders erupted in 1889-1890 as the real wage of Argentine workers declined with the rising price level. Domestic political strife further reduced the willingness of foreign investors to hold Argentine securities. The questionable fiscal and monetary policies drained the banking system of specie, provoked multiple banks to experience runs beginning in 1890, and thus ushered in a financial crisis. A series of last-minute tax and fiscal reforms in the summer of 1890 slowed down the economic decline, but did not prevent the ensuing financial crisis.

Even though the Baring Crisis had its origins in Argentina, its effects were quickly felt in other parts of the world, including London. ${ }^{6}$ Baring Brothers, the firm that underwrote most of Argentina's foreign debt issues, was not sheltered from that country's problems. The investment bank was saddled with the Buenos Aires Water Supply and Drainage Loan, a new debt issue that the investment house successfully failed to sell on the London market (Eichengreen, 1995). On the verge of bankruptcy and unable to meet its debt obligations, the House of Baring notified the Bank of England of its financial problems in early November 1890. The central bank pooled resources from the Bank of France, Russia's central bank, and British financial institutions to form a rescue fund to save the troubled financial institution that threatened to bring down British

\footnotetext{
${ }^{6}$ Following (Eichengreen, 1999; della Paolera and Taylor, 2001), we use the phrase "the Baring Crisis" to refer to both the distress in Argentina and the problems of the House of Baring in London; however, some scholars more narrowly refer to the Baring Crisis as applying only to the events in England and refer separately to the Argentine Crisis (Bordo and Murshid, 2001). We view the two events as being importantly linked.
} 
financial markets. The rescue operation succeeded and prevented a general financial collapse on European markets. Although actions by the Bank of England avoided a major financial collapse on European markets, the central bank did little to help debt-ridden Argentina.

Argentina defaulted on nearly $\$ 48$ million of debt in 1890 , which ended up constituting nearly 60 percent of the world's defaulted debt in the 1890s. After the Argentine government and the House of Baring failed to come to an agreement, Nathan Rothschild formed a committee of leading financiers to restructure the country's debt obligations. The committee demanded that the Banco Nacional transfer funds to service the country's short-term debt obligations (Eichengreen, 1999). In exchange, the committee agreed to underwrite a bond issue that could meet Argentina's remaining debt service for a period of three years. Argentina subsequently experienced a severe banking crisis in January 1891, in part, because of Banco Nacional's weakened financial position brought on by its transfer of assets to British creditors and its support of the Bank of the Province of Buenos Aires. The financial crisis worsened. The Bank of London and River Plate was the only bank that did not close its doors during the crisis. Argentina's real GDP fell by 11 percent between 1890 and 1891. Argentina suffered a deep recession for several years and did not fully recover from the crisis until the turn of the century, following a debt workout and more than a decade of monetary and fiscal reforms.

There is some evidence that the Argentine crisis may have spilled over to other countries in the region. Triner and Wandshneider (2005) suggest that the Baring Crisis had significant effects on Brazil. Bordo and Murshid (2001) examine cross-country correlations in weekly sovereign bond prices for seven countries in the year 1890 and find some evidence of regional contagion. Most studies, however, are not very clear as to whether the decline in sovereign debt prices was global in nature or confined to Latin America. For example, Fishlow (1989, p.88) noted that, "Not only did Argentine issues immediately move to substantial discounts on the London market, so also did those of other peripheral countries. Many were forced to reduce their debt service in the years that followed." He also suggests that other emerging market borrowers 
may have experienced a slower recovery from the crisis in comparison to Argentina. Suter (1992) suggests that the Argentine default may have been part of a broader episode of defaults in the 1890s. Kindelberger (1984) argues that the crisis spread to other Latin American debtors and emerging market borrowers in the European periphery, and McLean (2006) suggests that the crisis was international in nature and spread from Argentina to Australia. Given that previous research has not systematically analyzed the effects of the Baring Crisis on other emergingmarket economies, this paper focuses on determining whether the Baring Crisis was a regional or global emerging-market crisis.

\section{Movements in Emerging Market Yield Spreads}

\section{A. Time Series Evidence}

To provide some insight into the regional and global aspects of the Baring Crisis, we collected weekly prices on long-term government bonds from the Economist with maturities greater than 10 years. $^{7}$ The database contains over 15,000 weekly observations of bond price data from the London Stock Exchange for 41 countries and British colonies, for the period 18871895. ${ }^{8}$ Unlike Ferguson and Schularick's (2006) database of annual sovereign yield spreads, our sample of emerging market borrowers employs the same long-term bond for the entire sample period. The Ferguson and Schularick sample of annual interest rates splices two different bond series for many countries in 1889 and 1890, making it difficult to analyze the effects of the Baring crisis on sovereign risk. ${ }^{9}$ There are several reasons our analysis focuses on the sovereign

\footnotetext{
${ }^{7}$ Par value for all bonds in our sample was 100 pounds sterling. Maturity length depended on availability.

${ }^{8}$ For a discussion of the terms of each bond employed in the analysis, see the data appendix.

${ }^{9}$ In terms of coverage, our sample and the Ferguson and Schularick database are quite consistent with the exception of China and several smaller British colonies (i.e., Ceylon, Hong Kong, Mauritius, and Straits Settlement) whose bonds infrequently traded on the London market (see the Economist). China did not have a single bond series that traded on the London market for the entire period from 1886-1896. We also did not include Bulgaria and Denmark, two countries that only had a couple of years of bond data towards the end of our sample period.
} 
debt market to measure the economic effects of the Baring Crisis. First, annual GDP estimates and other macroeconomic data (such as investment spending) are only available for high-income countries and a handful of emerging markets for the gold standard period. Second, many scholars have questioned the quality of nineteenth century GDP estimates, especially for the emerging market sample, since the figures are often constructed by back-casting and interpolation between decadal benchmarks. ${ }^{10}$

In contrast, the sovereign debt market was very liquid during the gold standard period and data are available at the weekly frequency for most emerging market countries. Highfrequency data can be used to identify the effects of important events and policies on sovereign debt markets and to measure the overall impact of the crisis on country risk during this turbulent period. The sovereign debt market likely provides greater insight into the global effects of the Baring Crisis than broad macroeconomic indicators, such as GDP, given its wider coverage, higher frequency, and higher quality.

We constructed yield spreads - or the country risk premium - for each country or colony, which is defined as the current yield on a sterling bond for country or colony $i$ minus the yield on the "risk-free" British consol at time $t .{ }^{11}$ To quantify the regional effects of the crisis, Figures 1-5 show yield spreads for the 12 Latin American countries in our sample. Each figure contains a vertical line, denoting the outbreak of the crisis in Argentina. We dated the onset of the crisis to the summer of 1890 based on our reading of the secondary literature and the Investor's Monthly Manual (IMM) - a widely-read British financial publication that provides a weekly summary of important events affecting the London money market. Although one might choose a slightly different date to mark the genesis of the crisis, as shown in Table 1, the IMM reported a cluster of economic and political events that occurred in July and early August 1890, suggesting that British

\footnotetext{
${ }^{10}$ See Maddison (2003) for a discussion.

${ }^{11}$ France, Netherlands, and the United States issued debt in their domestic currency during this period. All three countries were on the gold standard from 1880 until the outbreak of World War I. We calculated the country risk premium for these three countries by subtracting the current yield of the domestic currency bond minus the current yield on the British consol.
} 
investors were becoming particularly concerned with the situation in Argentina at this time. The Banco Nacional, a major Argentine national bank, informed Baring Brothers in July that it would suspend service on its foreign debt obligations, signaling a deeper banking and debt crisis was emerging. Finance Minister Francisco Uriburu needed to pass a package of fiscal reforms so that the note issues used to prop up the banking system were not seen as the only part of the adjustment process. His reform package failed, and he resigned in early July. The government tried to lend to note-issuing banks to prevent a liquidity crisis, but without the reform package, a banking crisis was not averted, and runs on banks began. A few weeks later, a group of military officers unsuccessfully tried to overthrow the Argentine government. President Miguel Juarez Celman then resigned on August 6,1890, in response to public discontent over his decision to pursue policies of open inflation and acceptance of external default rather than liquidation of the "official" banks. ${ }^{12}$

The events highlighted by the financial press seem to have signaled to the London bond market that Argentina had entered into a serious financial crisis in July and August 1890, and that foreign investors were reassessing Argentina's credit risk. Figure 1 shows the country risk premium for Argentina. Yield spreads for Argentine sterling bonds declined from 1887 until 1889 before dramatically increasing from the summer of 1890 until early 1892 . The country risk premium fell from its high of 1,400 basis points in 1892 to approximately 800 basis points by 1896.

It also appears that the financial press was reconsidering credit risk in other Latin American emerging market borrowers. Figure 1 also shows the country risk premia for Brazil and Chile. The country risk premium for Brazil rose from 200 basis points in the late summer of 1890 until it reached its peak at more than 550 basis points in late 1892. The increase in the yield

\footnotetext{
${ }^{12}$ The Foreign Securities Section of the Economist also began devoting more attention to Argentina's economic problems during this period. The Stateman's Yearbook (1892, p. 331) noted that, "The events of July 1890, which caused the resignation of President Juarez Celman and a severe crisis, greatly disturbed the resources at the disposal of the Government during the last year."
} 
spread may partially reflect news about domestic political instability in the country. The Brazilian yield spread then declined in 1892 , briefly rises in 1894 , and then falls for the remainder of the sample period. The country risk premium for Chile is quite stable until the outbreak of the Baring Crisis. The yield spread for Chile increased in 1890-91 following the outbreak of a brief civil war, before stabilizing at 225 basis points in 1892 . The country risk premium rose again in late 1893 and then declined to about 210 basis points.

Figure 2 shows yield spreads for Colombia, Nicaragua, and Honduras. The interest-rate differential for Colombia declined in the years leading up to the Baring Crisis. Country risk for Colombia rose for the next several years and averages more than 3,000 basis points by the end of 1896. For Nicaraguan bonds, the yield spread was generally flat in the late 1880 s before rising gradually after the Baring Crisis. Country risk for the Central American country increased several thousand basis points in the early to mid-1890s following the outbreak of a war with Nicaragua (Economist, January 27, 1894, p. 122). The yield spread for Honduras declined from nearly 20,000 to 5,000 basis points prior to the onset of the Baring Crisis. The yield spread then increased to 25,000 basis points in 1893 before falling to 15,000 basis points in $1895-96$ after the conclusion of a war with its Central American rival. ${ }^{13}$

Figure 3 shows yield spreads for Costa Rica and Guatemala. The yield spread for Costa Rica fell by approximately 200 basis points in the years leading up to the Baring Crisis. Country risk for the Central American country then increased after the crisis to more than 1,500 basis points when the sovereign defaulted on their external debts in 1895 . The country risk premium for Guatemala fluctuated by around 400 basis points until the summer of 1890 when the yield spread increased to more than 1,000 basis points. Yield spreads for the Central American country then declined to approximately 600 basis points in 1892-93. Interest-rate differentials for Guatemala

\footnotetext{
${ }^{13}$ We also have some limited data on sovereign bond prices for Ecuador, El Salvador, and Peru. Although the Economist stopped reporting weekly bond prices for the three countries in 1891-1892, sovereign debt prices display time series behavior similar to the other Latin American countries up to this point in time. Bond prices declined approximately 30 to 50 percent for these countries.
} 
increased in 1894 to more than 1000 basis points as the country defaulted on its foreign debt obligations. Yield spreads then declined to a level of 900 basis points in 1896 after the country agreed to a debt workout with bondholders.

Figure 4 shows the country risk premia for Mexico and Paraguay. The yield spread on Mexican bonds is flat in the early part of the sample and then gradually rises from 360 to 500 basis points between July 1890 and June 1892. The yield spread for Paraguay declined in the early part of the sample and then increased from 100 basis points to more than 1,000 basis points following a debt default that lasted until 1897. Country risk for Uruguay and Venezuela are presented in Figure 5. Country risk for Uruguay followed a U-shaped pattern, dramatically falling from a level of more than 450 basis points in the late 1880 s to slightly more than 100 basis points on the eve of the Baring Crisis. The yield spread then climbed to over 600 basis points by 1892 . The rise in the country risk premium may reflect, in part, news of a banking and commercial crisis in Montevideo that helped lead to a severe recession. Uruguayan debt prices are then not quoted on the London market after the country briefly defaulted on its debt obligations. Country risk for Venezuela declined by approximately 400 basis points prior to the onset of the Baring Crisis. Yield spreads then rose to over 900 basis points in 1892 before declining to a level of 500 basis points by the end of the sample.

Consistent with the graphical evidence, the weekly record of the sovereign bond market from the financial press suggests that, in addition to any country-specific events that moved sovereign spreads, the Baring Crisis may have been a common factor driving Latin American securities in the early $1890 \mathrm{~s} .{ }^{14}$ Indeed, the newspaper clippings of the Corporation of Foreign Bondholders (a British entity representing the interests of sovereign debt holders) suggest that the Argentine crisis may have had real economic effects on other Latin American countries. For example, the Star and Herald commented on how the banking and merchant relationships

\footnotetext{
${ }^{14}$ Suter (1992, p. 81) states: "Thus, the crisis was triggered by the state insolvency of Argentina, the Latin American debtor country most strongly incorporated into the Atlantic economy."
} 
between Argentina and Paraguay transmitted the financial crisis to the landlocked South American country ${ }^{15}$, and The Bullionist wrote:

"Paraguay, like Argentina, Uruguay, and Brazil, is undergoing a financial crisis, and this crisis was recently described by the Finance Minister to Congress in the form of a report... They were traceable, without a doubt, to the condition in the Argentine. There has been a general falling-off in trade, which has given rise to a feeling of uneasiness and want of confidence, and since the beginning of 1890 things have been getting worse."

The Buenos Aires Standard discussed the economic effects of the Argentine crisis on Uruguay, a country with close financial and merchant ties to the South American country:

"It must be borne in mind that such is the intimate connection between both countries that as long as Argentines suffer from crises, Orientales [The Oriental Republic of Uruguay] cannot expect to flourish." 17

In January 1891, the South American Journal called the "the violent economic crisis, which overtook the country last July...a logical repercussion of the Argentine crisis and the English crisis." 18

The events in Barings seem to have also affected Central American borrowers. The South American Journal wrote the following about Costa Rica in 1891:

"The fall in Costa Rica "A" and "B" bonds was not in any way due to the internal affairs of the country, but due to the disturbances in July last between Guatemala and Salvador, followed by the troubles in the Argentine Republic, producing a depression of all stocks." 19

It appears that financial markets may have also been reassessing the debt of the region en

masse. The reassessment may be due to a "wake-up" or a common creditor channel, two explanations given for contagion during the Asian financial crisis. ${ }^{20}$ The Economist, for example, frequently commented on the effects of events in Argentina on the sovereign debt prices of other

\footnotetext{
15 "The Argentine crisis has affected the banks and mercantile houses of Paraguay, and under the influence of the withdrawals of minted money by the Argentines, paper money has suffered a certain depreciation." Star and Herald, May 14, 1891.

${ }^{16}$ The Bullionist, April 23, 1892.

${ }^{17}$ Buenos Aires Standard, April 21, 1890.

${ }^{18}$ South American Journal, January 24, 1891.

${ }^{19}$ South American Journal, July 18, 1891.

${ }^{20}$ See Radelet and Sachs (1998) and Eschweiler (1997) for evidence of a wake up call in the 1997 East Asian Crisis.
} 
countries in Latin America. The Economist referred to Central and South American securities in the early 1890s as a group distinct from other countries and regions of the world (while at the same time noting the importance of country-specific events for all securities). Consider the following report from the July 5, 1890, Foreign Securities Section of the Economist:

"The feature in South American descriptions has been the heavy fall in Argentine Cedulas, which close about 3 percent lower all round, although the final prices are somewhat above the usual. The fall has been due to the great rise in the gold premium at Buenos Ayres-which has resulted from the passing by the National Bank of its demand. This action of the Bank has raised anew great doubts as to its stability and its ability to get through the present difficulties without shipwreck. All other issues such as Uruguay, Brazilian, \& c., have given way sympathetically."

The Times of London also frequently noted that Latin American securities declined in price while debt prices for other emerging markets were generally flat:

"Business has been quiet in the Foreign Market, but the tone was fairly steady, and except in the case of South American issues, which were again weak on very discouraging news from Buenos Ayres, there are not many changes to report." 21

The financial press also suggested that investors had difficulty in pricing Latin American bonds. This lends credence to the notion that asymmetric information may have played a role in the sell off of Latin American securities. On the eve of the financial crisis, June 5, 1890, the Financial News noted the lack of information about Latin American securities available to bond market investors.

"The market for South American securities is much more extensive than is generally supposed, and in it you get a large variety...The dealers are few in number, and they work well together, and as a consequence, when there is any movement they secure the fat, and the public get the greater portion of the lean. As a matter of fact, it may be greatly doubted if the public know much about the features of the market - that is to say, if they have the adequate knowledge which would enable them to speculate with any degree of confidence. Of course, most people know something - usually rather too much - about Argentina, Brazilians and Uruguays; but when they get to such securities as Paraguayan and Colombian bonds, or to the issues of such States as Nicaragua and Salvador, they feel, to say the least of it, that, unlike the dyer, their hand is not accustomed to that which it works...The whole market, as we have shown, abounds in anomalies." 22

\footnotetext{
${ }^{21}$ The Times, August, 24, 1890.

${ }^{22}$ Financial News, June 5, 1890.
} 
The Economist also noted a similar problem in assessing the value of Latin American securities:

"Amidst the mass of literature which has seen the light during the past few years concerning the River Plate, Brazilian, Chilian, Peruvian, and other South American Republics and their finances, comparatively little has been forthcoming to show the British investor what the liabilities of those States really amount to...And beyond this, almost the whole of them are weighted down by inconvertible and greatly depreciated currencies, in which their revenue and expenses are calculated and in which their internal liabilities are expressed; and those internal liabilities, direct, contingent, and provincial, are so numerous and difficult to measure that in such a state as the Argentine Republic it appears almost hopeless to make order of to them." ${ }^{23}$

The financial press noted that, during the Baring Crisis, it was perhaps easier for investors to be indiscriminate rather than try to accurately determine which countries would weather the storm. (A similar assessment may have occurred during the early stages of the East Asian crisis. $)^{24}$ As the New York Times wrote three years after the start of the crisis:

"It must be borne in mind that Brazil has always punctually met all its obligations and therefore its credit ought to be reasonably good. Moreover, the Oest de Minas Railway is a fairly good property, and the proposed extension will develop a region of the country rich in minerals and of wonderful agricultural capabilities... But the public does not discriminate - or rather, in times like the present, refuses to be attracted by probabilities. South Americans are in general disrepute, and it must be admittedly, deservedly." 25

The Financial News reported the reaction of bond prices in Latin America in a similar fashion:

"Then the distrust produced by the financial catastrophe in the Argentines and Uruguay has naturally reacted on Brazil, and led most people of ordinary caution to withdraw their money from the country, as being tarred with the same brush as other South American republics. Under such conditions, nothing but the most conservative financial policy could prevent Brazil from suffering severely from the withdrawals of gold and restriction on foreign business which were inevitable." 26

\footnotetext{
${ }^{23}$ Economist, October17, 1891.

${ }^{24}$ For example, Radelet and Sachs (1998) describe the early stages of the 1997 East Asian financial crisis as one in which "creditors made little effort to distinguish between these Southeast Asian economies."

25 "England's Financial Woes: The Ever-Widening Effects of the Baring Failure," New York Times, May 8, 1893, p.12. In reference to Uruguay, the South American Journal (August 15, 1891) stated, "The terrible Argentine muddle continues to tell against us, and although our situation is simplicity itself compared to theirs, we are bound to suffer for the sins and discredit of our big neighbors."

${ }^{26}$ Financial News. November 6, 1891.
} 
To form a preliminary assessment of whether the effects of the crisis had effects on all emerging market borrowers, and not just regional sovereign borrowers, Figure 6 graphs the average interest rate for Latin and non-Latin emerging markets as well as the core countries in our sample.

We divided our entire sample of countries and colonies into three groups to analyze yields of (1) Latin American countries, (2) non-Latin Emerging markets, and (3) core or highincome European countries and the United States, in the period surrounding the Baring Crisis. Our unweighted yield index for Latin America consists of 12 countries: Argentina, Brazil, Chile, Colombia, Costa Rica, Guatemala, Mexico, Nicaragua, Paraguay, Uruguay, and Venezuela. ${ }^{27} \mathrm{We}$ construct an un-weighted yield index of non-Latin American emerging markets using 22 countries: Austria, British Guiana, Canada, the Cape of Good Hope, Egypt, Greece, India, Italy, Jamaica, Japan, Natal, New South Wales, New Zealand, Norway, Queensland, Russia, South Australia, Sweden, Tasmania, the Ottoman Empire (Turkey), Victoria, and Western Australia. ${ }^{28}$ The core country index consists of five high-income European countries (Belgium, France, Germany, Netherlands) and the United States. As shown in Figure 6, interest rates are generally quite flat over the sample period for the non-Latin Emerging markets and the core countries. The small increase in interest rates for the non-Latin Emerging Market Index can be completely attributed to Greece and its debt default in 1893. Bond yields are flat for the non-Latin emerging markets over the sample period if Greece is excluded. Interest-rates for Latin American emerging markets, however, display a very different pattern, rising from about 800 basis points in 1887 to

\footnotetext{
${ }^{27}$ Although Portugal and Spain are not in the Latin American sample, we also test throughout the paper whether our results are sensitive to the inclusion of these two countries in the Latin American sample given that the two European countries had significant trade linkages with their former Central and South American colonies. One argument for including Portugal and Spain as part of the Latin American sample is that remittances may have been important for these two countries during our sample period. As shown by Esteves (2004), remittances from Brazil were especially important for Portugal. The large drop in remittances during the early 1890 help explain why Portugal left the gold standard. We excluded Honduras from Figure 6 given that its bonds were in deep default. The coupon rate for Honduras was 2.5 times greater than the price of the bond for much of our sample period.

${ }_{28}$ British Guiana is included in the non-Latin emerging market sample because it is a member of the British Empire whose bonds were guaranteed by Her Majesty's Government.
} 
more than 1,200 basis points by the end of 1895 . One reason that rates continued to rise in other Latin American countries several years after the onset of the crisis may have been related to the ongoing failure of Argentina to fully renegotiate its debt and establish a stable monetary environment or the fact that European investors were unable to assess the severity of the crisis due to lack of information or incomplete information. Even though the Arreglo Romero arrangement to reduce interest payments for five years was concluded in 1893 and GDP had begun to recover, no agreement for defaulted provincial debt and railway guarantees was concluded until after 1897 (Fishlow, 1989). Since, as noted above, Argentina may have been seen as a bellwether economy that was used by investors to gauge the fiscal and monetary health of other borrowers in the region, the delay over a full debt settlement may have raised concerns among foreign investors that other less-developed countries in the region would face even greater challenges in restoring fiscal and monetary order to their economies after the crisis. The financial press continued to report, three years after the onset of the crisis, how economic and political events in Argentina had a significant effect on bond prices throughout the region.

"South Americans have been unsettled, in consequence of the Ministerial crisis in Buenos Ayres, the Cabinet having resigned, and the resignation of the President considered probable, if not imminent." 29

We more carefully address the movement of the bond spreads later in the paper when we are able to control for country-specific factors.

\section{B. Summary Statistics of Changes in Yield Spreads}

The time series graphs of yield spreads and the interest-rate indexes present suggestive evidence that the Baring Crisis had a larger effect on Latin American borrowers compared to other emerging markets and core countries. To complement these figures, Tables 2-4 present summary statistics of changes in yield spreads between 1890 and 1894 for Latin American

\footnotetext{
${ }^{29}$ Economist, July 8, 1893.
} 
borrowers, non-Latin American emerging market countries, and the core countries in our sample. We examine the performance of emerging-market, interest-rate differentials by analyzing the oneyear, two-year, and four-year horizons after the onset of the Baring crisis: (1) July 1890-June 1891, (2) July 1890-June 1892, and (3) July 1890-June 1894 . $^{30}$

Table 2 shows that yield spreads for most Latin American countries increased dramatically in the early 1890s. Interest-rate differentials for Argentina, Colombia, and Honduras rose by more than 670 basis points in the first year of the crisis. The average yield spread for Guatemala, Paraguay, and Uruguay increased by more than 190 basis points in the one-year window. The average yield spread for Chile, Costa Rica, Venezuela, Mexico, and Nicaragua increased approximately 81 basis points in the year following the outbreak of the financial crisis in Argentina. Overall, Latin American yield spreads increased an average of 844 basis points in the first year after the onset of the crisis. As Table 2 shows, the large increase in yield spreads remains, even when Argentina is omitted (or when we include a broader definition of Latin America that includes Spain and Portugal).

Table 2 also shows that the increase in yield spreads is generally more pronounced in the longer sub-sample periods. Yield spreads for Argentina rose 682 basis points two years after the onset of the crisis and 689 basis points after five years. Country risk for Brazil increased 227 basis points between July 1890 and June 1892, and 130 basis points between July 1890 and June 1894. Chilean yield spreads increased 44 and 73 basis points in the two-year and four-year windows.

Interest-rate differentials also rose for the smaller Latin American republics. Yield spreads for Colombia, Honduras, and Portugal all increased more than 700 basis points in the two-year window and more than 800 basis points in the four-year window. The country risk

\footnotetext{
${ }^{30}$ Consistent with the graphical analysis of yield spreads, we selected July 1890 as the starting date of the Baring crisis. Changing the crisis date to correspond to other important events in 1890, such as the Bank of England's announcement that they would rescue the House of Baring, does not change the basic tenor of the results that are presented in the tables and regressions. Our reading of the financial press suggests that the crisis had subsided by 1895 . For example, see the Financial News, July 27, 1895, p.1.
} 
premium for Costa Rica, Guatemala, and Nicaragua increased more than 97 basis points in the two-year window and more than 159 basis points in the four-year window.

The yield spread for Paraguay increased 401 basis points in the two-year sub-sample and 908 basis points between July 1890 and June 1894. Sovereign debt prices for Spain increased 61 and 83 basis points in the two-year and four-year windows, respectively. Unfortunately, interest rate data for Uruguay are not available for the two longer windows (April 1890-April 1892 and April 1890-April 1894). The Economist stopped reporting debt prices for this country after it briefly defaulted on its bonds and arranged a debt conversion with its bondholders in the early 1890s. Yield spreads for Venezuela increased 224 basis points in the two-year window and 254 basis points in the four-year window.

The average yield spread for the Latin American sample increased 759 and 1,608 basis points in the two- and four-year periods after the onset of the financial crisis. As shown in Table 2, the large decline in the value of Latin American securities for the two- and four-year crisis periods are robust to including Spain and Portugal as part of the Latin American sample or dropping Argentina from the analysis.

A very different picture emerges if we examine the time-series and cross-sectional behavior of non-Latin American emerging market borrowers. As Column (1) of Table 3 shows, the average yield spread for non-Latin American emerging markets decreased by nearly 1 basis point in the first year after the onset of the crisis. With the exception of Greece, yield spreads did not rise or fall more than 13 basis points for the non-Latin Emerging market sample. Column (2) reports summary statistics for yield spread changes for the non-Latin American emerging markets between July 1890 and June 1892. The results largely resemble the findings in Column (1) with yield spreads increasing about eight basis points over this period. The increase in country risk is almost entirely driven by Greece, whose interest-rate differential rose more than 92 basis points in the two-year window. If Greece is excluded from the sample, then yield spreads increased by almost four basis points. 
In the four-year window (Column 3), yield spreads increased by nearly 57 basis points for our sample of non-Latin American emerging markets. The result is driven again by Greece, which defaulted on its debts in 1893 . Yield spreads only rise by eight and a half basis points if Greece is excluded from the sample. Nevertheless, even if Greece is included in the sample, the average yield spread in Latin American countries increased more than 1,600 basis points in the four-year window compared to an 57 basis point increase in country risk in the non-Latin Emerging market sample. ${ }^{31}$

Table 4 reports summary statistics for the five core countries in the sample. Yield spreads were generally flat for the core countries in the one-year window. The country risk premium moved less than 21 basis points for all of the core countries. As a group, interest-rate differentials declined by approximately nine basis points. As shown in Columns (2) and (3), the summary statistics for the two-year and four-year windows resemble the results from Column (1). The country risk premium moved less than 30 basis points for Belgium, Germany, and the Netherlands. The United States experienced a 31 basis-point increase in its yield spread in the four-year window. French bonds showed the greatest movement in the longer windows, with yield spreads falling 28 basis points between July 1890 and June 1891 and declining 23 basis points in the four-year window. As a group, country risk moved less than three basis points for the high-income/core countries in our sample. Overall, yield spreads were generally very flat in the core countries during the early 1890 s.

\footnotetext{
${ }^{31}$ Given that many Latin American countries defaulted on their sovereign debts during this period, we also calculated summary statistics using bond returns as opposed to yield spreads. The basic tenor of the results remains unchanged using this alternative measure. The results are available from the authors upon request.
} 


\section{What Factors Account for the Movement in Bond Yields during the Crisis?}

\section{A. Panel Model and Data}

In order to further assess the regional nature of the crisis and control for country-specific factors, we now turn to analyzing the determinants of yield-spread movements over the period 1886-1896. We construct a panel data set consisting of annual data for our sample of 35 emerging market borrowers, which includes macroeconomic indicators, trade variables, institutional arrangements and political factors, and country-specific controls. ${ }^{32}$ We employ a series of country fixed effects models to analyze the determinants of sovereign yield spreads. In the spirit of Ferguson and Schularick (2006) and Flandreau and Zumer (2004), our strategy is to employ a variety of indicators that were readily available and widely used by emerging market investors in the late nineteenth century to assess country-specific financial risk. In an ideal world, we would also like to include modern macroeconomic variables such as gross domestic product to measure the economic effects of the crisis; however these data are available for only three out of ten Latin American countries in our annual panel sample (Brazil, Chile, and Uruguay). ${ }^{33}$ This is in part why we rely on these readily available indicators - so that we can construct a data set with the largest possible number of potential determinants of yield spreads. Moreover, in contrast to the approach in Ferguson and Schularick (2006), our data exercise permits us to include fixed effects to control for other macroeconomic determinants that may have influenced yield spreads. We test whether the Baring Crisis can account for the movement in prices in Latin-America or whether the movement in prices in these countries is simply accounted for by macroeconomic factors or other

\footnotetext{
${ }^{32}$ One reason we shift our analysis from weekly to annual frequency is so that we can control for macroeconomic factors that influence yield spreads. For earlier papers exploring yield spreads during the gold standard era, see Bordo and Rockoff (1996) and Obstfeld and Taylor (2003).

${ }^{33}$ The most recent historical GDP estimates are available from Angus Maddison's website at www.ggdc.net/maddison/. Prados de la Escosura (2000) provides an alternative dataset of historical GDP estimates for the gold standard period, 1870-1913. Although his sample covers 23 countries, it only includes one Latin American country (Argentina) and gives GDP estimates for five benchmark years: 1870, 1880, 1890, 1900, and 1913.
} 
country-specific effects. We also develop some measures that are used to assess whether the gold standard or trade linkages were potential channels of transmission from Argentina to other emerging-market borrowers.

To capture how investors viewed the macroeconomic status of emerging market borrowers, we employ five measures: (1) a variable that measures interest-rate movements in emerging markets; (2) the budget deficit (expenditures-revenues) as a share of revenue; (3) the ratio of total public debt (internal and external) as a share of government revenue; (4) a dummy variable indicating whether the country is in default and has stopped servicing its foreign debt; and (5) the natural logarithm of the British wholesale price index. To capture general fluctuations in interest rates, we include an emerging market control that is the un-weighted average interest rate of 22 non-Latin American emerging market borrowers minus the interest rate on "risk-free" British consol. As for the other macroeconomic variables, a country with sound fiscal policy (as reflected by a small or negative ratio) should have lower sovereign risk and a lower probability of default since it would have a better capacity to service its debt obligation out of revenue or a greater ability to respond to other exogenous shocks which otherwise might make debt repayment more difficult. A country with a lower debt-to-revenue ratio should have a greater ability to repay its debts, suggesting, ceteris paribus, less sovereign risk and a lower probability of default. A sovereign debt default is a strong signal to the bond market that the country has serious financial problems and is a high credit risk. The price-level variable is included to capture the effects of general deflation, which may have increased the real debt burden of sovereign borrowers.

Trade statistics were important for assessing sovereign risk in emerging markets during the gold standard era since measures like gross domestic product (GDP) had not been developed, since taxes on trade were a major source of revenue, and since exports provide a means for generating foreign currency to service debt denominated in sterling or gold. Annual import and export figures were regularly reported in investment manuals such as the Statement's Yearbook and Fenn on the Funds. In particular, we consider two measures of trade that investors used to 
assess the financial health of the borrower: (1) the trade balance (exports minus imports) scaled by exports, and (2) the sterling value of exports per capita. Countries with a current account surplus were generally regarded as having a greater ability to service their foreign debts by emerging market investors. As Ferguson and Schularick (2006) note, since nineteenth-century investors did not have GDP per capita at their disposal (to indicate the degree of institutional and economic development of a country), they used exports per capita as an alternative measure to proxy for the risk-reducing factors associated with economic development.

Institutional and political factors may also have been used by investors to price sovereign debt during the late nineteenth century. Ferguson and Schularick (2006) have argued that membership in the British Empire lowered the risk associated with holding colonial bonds because Her Majesty's government guaranteed debt repayment. We therefore code a dummy variable that takes a value of one if the borrower was a member of the British Empire. Bordo and Rockoff (1996) argue that the gold standard was a "good housekeeping seal of approval" that lowered sovereign risk for emerging market borrowers during the gold standard period. The gold standard was a contingent rule that solved the classic time inconsistency problem by tying the hands of the monetary and fiscal authorities. However, Bordo and Murshid (2001) suggest that adherence to the gold standard may also facilitate the transmission of shocks or contagion. Finally, Eichengreen and Sachs (1985) suggest that strict adherence to the gold standard may make it more difficult to pursue the beggar-thy-neighbor policy of devaluation. We thus code a dummy variable that takes a value of one if a country was a member of the gold club using goldstandard adoption dates from Meissner (2005). As for the political variables, we code international and civil conflict variables to capture the effects of local and interstate conflicts on sovereign risk based on Ferguson and Schularick (2006). The inclusion of these conflict variables is motivated by the frequent discussion of the effects of coup d'etats and wars on bond prices in the Foreign Government Securities Section of the Economist. 
We use a number of variables to test for the presence of a regional effect in Latin America after the onset of the Baring Crisis. First, we code a crisis variable that takes a value of one beginning in 1890 until the end of the sample period (1896), when it is generally agreed that Argentina had recovered from the crisis. This variable potentially captures the overall effect of the crisis on all emerging market borrowers. Second, we interact the crisis indicator variable with a Latin American indicator variable to test if, ceteris paribus, yield spreads in Central and South America increased following the outbreak of the financial crisis.

We also included some measures to capture potential channels through which the crisis may have spread. First, we coded the emerging market borrower's trade share: exports and imports to the UK as a share of total trade. We use this measure to examine whether changes in trade affected bond spreads. We interacted the UK trade share variable with the Latin American dummy to analyze the effect of British trade on Central and South American yield spreads. Given England's role in the Baring Crisis, an interaction term between the UK trade share variable and the crisis dummy is also constructed to see if the crisis spread globally through trade ties with England. As an additional channel, we also interacted the crisis indicator variable with an indicator variable for being on the gold standard in order to test whether countries that had fixed exchange rates had a differential effect associated with the Baring Crisis.

The empirical model can be written as:

(2) YLDSPREAD $_{i t}=\beta_{i}+\beta_{1}$ EMGCONTROL $_{t}+\beta_{2}$ DEFAULT $_{i t}+\beta_{3}$ BUDGETBALANCE $_{i t}+$ $\beta_{4}$ DEBT $_{\text {REVENUE }}+\beta_{5}$ TRADEBALANCE $_{\text {it }}+\beta_{6}$ EXPORTSPC $_{\text {it }}+\beta_{7}$ EMPIRE $_{\mathrm{i}}+\beta_{8} \mathrm{GOLD}_{\mathrm{it}}+$ $\beta_{9}$ GOLD $^{*}$ CRISIS $_{\text {it }}+\beta_{10}$ INTERSTATE $_{i t}+\beta_{11}$ CIVIL $_{i t}+\beta_{12}$ PRICELEVEL $_{t}+$ $\beta_{13}$ PRICELEVEL $_{\mathrm{t}}+\beta_{14}$ CRISIS $_{\text {it }}+\beta_{15}$ LATIN $_{\mathrm{i}} *$ CRISIS $_{\mathrm{it}}+\beta_{16}$ UKTRADESHARE $_{\mathrm{it}}+$ $\beta_{17}{ }^{*}$ UKTRADESHARE $_{\mathrm{it}}{ }^{*}$ CRISIS $_{\mathrm{it}}+\beta_{18}$ LATIN $_{\mathrm{i}} * \mathrm{UKTRADESHARE}_{\mathrm{it}}+\varepsilon_{\mathrm{it}}$,

where YLDSPREAD ${ }_{\text {it }}$ is the average current yield on a sovereign sterling (or gold) bond for country $i$ at time $t$ minus the current yield on the British consol and $\beta_{\mathrm{i}}$ is a country-specific intercept. The independent variables are defined as: 
- EMGCONTROL $_{t}$ is an unweighted index of the average current yield of 14 non-Latin emerging markets minus the current yield on "risk-free" British consols at time $\mathrm{t}^{3}$,

- DEFAULT $_{\text {it }}$ is a binary variable which is unity if country $i$ is in default at time $t$;

- BUDGET BALANCE $E_{i t}$ is revenues minus expenditures for country $i$ at time $t$;

- DEBT/REVENUE it $_{\text {is }}$ ratio of total public debt to government revenue for country $i$ at time t;

- TRADEBALANCE $E_{i t}$ is the current account position of country $i$ at time $t$;

- EXPORTSPC $\mathrm{C}_{\mathrm{it}}$ is the ratio of exports to population for country $\mathrm{i}$ at time $\mathrm{t}$;

- EMPIRE $_{\mathrm{i}}$ is a binary variable which is unity if country $i$ is a member of the British Empire (a time-invariant covariate in our sample period);

- $\mathrm{GOLD}_{\mathrm{it}}$ is a binary variable which is unity if country $i$ is on the gold standard at time $t$;

- GOLD*CRISIS it $_{\text {it }}$ in interaction term that is defined as country $i$ being on the gold standard and in the crisis period at time $t$;

- INTERSTATE $E_{i t}$ is a binary variable which is unity if country $i$ is involved in an interstate war at time $\mathrm{t}$;

- CIVIL $_{i t}$ is a binary variable which is unity if country $i$ is involved in a domestic war at time t;

- PRICELEVEL $L_{i t}$ is the natural logarithm of the UK wholesale price index

- LATIN $_{\mathrm{i}}$ is a binary value if country $\mathrm{i}$ is part of Latin America;

- CRISIS $_{\text {it }}$ is a binary variable which is unity for country $i$ after the onset of the Baring Crisis in 1890;

- LATIN $_{\mathrm{it}}{ }^{*} \mathrm{CRISIS}_{\mathrm{it}}$ is an interaction term which is unity if country $\mathrm{i}$ is located in Latin America and the year is 1890 or later;

- UKTRADESHARE ${ }_{i t}$ is country i's share of total trade with the UK at time $t$;

- CRISIS $_{\mathrm{it}}{ }^{*}$ UKTRADESHARE $_{\mathrm{it}}$ is an interaction term between the crisis variable and a country's total share of trade with the UK at time $t$;

- LATIN $_{\mathrm{it}}{ }^{*} \mathrm{UKTRADESHARE}_{\mathrm{it}}$ is an interaction term between the Latin American dummy and a country's total share of trade with the UK at time t;

- $\quad \beta$ are estimated coefficients;

- and $\varepsilon$ is a white noise error term capturing other influences on yield spreads.

For the dependent variable, we constructed annual yield spreads by averaging the weekly data used in the time series analysis from Section III. We primarily rely on data from Ferguson and Schularick (2006) for the construction of various macroeconomic and trade indicators, and augment their data for additional countries using information from British Board of Trade Publications, Fenn's Compendium, the Statesman Yearbook, and the Annual Reports of the Corporation of Foreign Bondholders. We calculated country trade shares with the UK using these same sources.

\footnotetext{
${ }^{34}$ Following Bordo and Rockoff (1996), Mauro, Sussman and Yafeh (2002), and Flandreau and Zumer (2004), we calculate the current yield on a sovereign bond by dividing the coupon by the price of the debt security.
} 


\section{B. Empirical Results of Panel Analysis}

The empirical results for our sample of 35 sovereign borrowers appear in Table $5 .{ }^{35}$ All models are estimated with country fixed effects in order to capture unobserved differences across countries. To control for correlation across countries in a given year, we clustered the standard errors on a group-year fixed effect. ${ }^{36}$ The group-year variable is constructed by dividing the sample into three groups - Latin, non-Latin, or core countries/colonies - and then multiplying the regional indicator by the year. ${ }^{37}$ We specified a dummy variable to measure the effect of the Baring Crisis on yield spreads given that there is statistical evidence of a trend break in the Latin American bond yields in $1890 .^{38}$ The break in yield spreads is more consistent with the "fast and furious" view of contagion of Kaminsky et al. (2003), as opposed to Forbes and Rigobon (2002) view, which suggests that shifts in coefficients are the way to test for contagion. Column (1) reports baseline results without the controls for the effects of the crisis. The baseline model captures roughly 84 percent of the variation in yield spreads. The country risk premium, ceteris paribus, is positively correlated with general movements in emerging-market interest rates, although the effect is only statistically significant at the 20-percent level. All else equal, a country in debt default has yield spreads that are more than 387 basis points higher than a sovereign borrower that is servicing its debt. An improved budget-deficit ratio reduces the country risk premium by nearly 30 basis points, but the effect is not statistically significant. The other

\footnotetext{
${ }^{35}$ The sample of 35 borrowers includes five high-income countries (Belgium, France, Germany, Netherlands, and the United States, 23 non-Latin emerging markets (Austria, British Guiana, Canada, Cape Colony, Egypt, Greece, India, Italy, Jamaica, Japan, Natal, New South Wales, New Zealand, Queensland, Portugal, Spain, Russia, South Australia, Sweden, Tasmania, Turkey, Victoria, and Western Australia) and seven Latin emerging markets (Brazil, Chile, Colombia, Costa Rica, Mexico, Uruguay, Venezuela). We drop Ecuador, Guatemala, Honduras, Nicaragua, Paraguay, and Norway from our earlier, weekly sample due to insufficient data on covariates. Argentina is excluded from the panel regressions because it is the crisis country.

${ }^{36}$ For a discussion on techniques for dealing with correlation in cross-sectional units in fixed effects models, see Cameron et al. (2006).

${ }^{37}$ The empirical results are also robust to estimating the model with heteroskedastic-consistent standard errors or clustering on year.

${ }^{38}$ Application of the Banerjee et al. (1992) unit root test indicates the presence of a trend break in Latin American bond yields in 1890 .
} 
macroeconomic and trade variables (the debt-revenue ratio, the trade-balance ratio, and exports/population) do not have statistically or economically significant effects on sovereign yield spreads. Adherence to the gold standard, the price level, and the conflict variables also do not have statistically significant effects on the country risk premium. ${ }^{39}$ The Latin and empire variables are dropped from the analysis since they are time-invariant covariates.

The second column of Table 5 presents results that include the Baring crisis indicator variable as well as the proxies used to examine the potential channels through which the crisis operated. Debt default continues to have a large economic and statistically significant positive effect on bond spreads. Yield spreads are positively correlated with the emerging-market interestrate variable, although the effect is not statistically significant. ${ }^{40}$ Consistent with the baseline specifications, the macroeconomic and trade variables generally do not have a statistically significant effect on country risk. The exception is exports per capita which significantly increases sovereign risk at the ten-percent level. Membership in the gold standard and the conflict variables also do not lower sovereign risk. We also find some evidence that countries with a larger share of trade with the UK have lower sovereign yields, although this effect is not economically or statistically significant. The price level variable also does not have a statistically significant effect on country risk. The statistical insignificance of the price level variable in the two regressions suggests that deflation does not contribute towards explaining the behavior of country risk in our sample period after controlling for other factors.

Turning to the variables specifically concerned with the crisis, the Baring Crisis does not seem to have impacted all sovereign borrowers: the crisis indicator variable is not statistically significant at conventional levels. However, there is some support for the hypothesis that adherence to the gold standard lowered sovereign risk during the Baring crisis: that is, the

\footnotetext{
${ }^{39}$ It may not be that surprising that the gold standard effect by itself is statistically insignificant, since with country dummies included, all the identification is off the time dimension; there are likely too few "switchers" during the 1886-96 period to estimate this effect precisely.

${ }^{40}$ The emerging market control is significant at the one-percent level if the price level variable is dropped from the analysis.
} 
interaction effect between the gold standard and the crisis variable is statistically significant at the one-percent level. Bond market investors may have viewed gold adherence as a signal that a country would pursue prudent monetary and fiscal policies during a period of financial turbulence. $^{41}$

Consistent with the summary statistics and graphical evidence presented earlier in the paper, the Latin-crisis variable (the interaction between a Latin America indicator variable and the Baring Crisis indicator) has a large positive effect on yield spreads that is statistically significant at the five-percent level. The point estimate suggests that the crisis increased yield spreads in Central and South America by 214 basis points. It also appears that trade may have been a channel through which the crisis spread. The UK trade share variable interacted with the crisis dummy increases country risk by roughly 20 basis points (evaluating the point estimate of 1 at the mean UK trade share of 20), although the effect is not statistically significant at conventional levels (19 percent level of significance). ${ }^{42}$ The UK trade share variable interacted with the Latin American raises country risk by approximately 80 basis points (evaluating the point estimate of 10 at the mean UK trade share in Latin America of 8). This additional effect on Latin American spreads is significant at the twenty-percent level of significance. ${ }^{43}$ To test the joint significance of the crisis variables, we took the partial derivative of yield spreads with respect to the crisis dummy variable. The three variables raise country risk by nearly 240 basis points for Latin American countries and are jointly significant at the one percent level. ${ }^{44}$

\footnotetext{
${ }^{41}$ On the other hand, the interaction may be picking up another way of measuring the net effect of the crisis in that departure from gold is often causally related to a financial crisis.

${ }^{42}$ We also estimated a model that included an additional independent variable: the Latin American crisis dummy interacted with the UK trade share variable. This triple interaction variable (Latin*crisis*UK trade share) is statistically significant at the five-percent level in the fixed effects model. However, the correlation between the Latin American crisis dummy and the triple interaction variable is 90 percent. Given the high correlation between the two interaction variables and the fact that the UK trade share variable is relatively constant over our sample period, we interpret the statistical significance of the triple interaction variable as evidence consistent with the baseline results reported in Column 2 of Table 5.

${ }^{43}$ We obtain similar results if Portugal and Spain are included as part of the Latin American sample. The results are available from the authors upon request.

${ }^{44}$ If we take the partial derivative of yield spreads with respect to the Latin American dummy variable, then we find that the interaction terms are jointly significant at the 10-percent level.
} 


\section{Discussion}

The two variables which drive the panel analysis, in terms of both economic and statistical significance, are debt default and the Latin American-crisis interaction effect. The economic interpretation of the debt default variable is relatively straightforward: countries that had a history of poor repayment and had defaulted borrowed at higher rates. The Latin Americancrisis dummy is open to greater interpretation. One interpretation is that the interaction term is simply capturing some omitted effect that is common to all Central American and South American borrowers during the crisis. Another interpretation is that the large and statistically significant coefficient on the Latin American-crisis interaction may indicate that European investors sold off or reduced their holdings of Latin American bonds following revelations of Argentina's economic problems and news of its debt default in 1890.

Investors may have not been paying adequate attention to individual country characteristics prior to the onset of the crisis or they may have responded by rebalancing their portfolios of emerging market debt. The behavior of sovereign yield spreads before and after the onset of the Baring Crisis is consistent with two possible explanations: (1) investors experienced a wake-up call and withdrew their funds from countries similar to Argentina and/or (2) a common creditor (British investors) reallocated their portfolio away from Latin American debt. A "wake up call" would suggest that Argentina's default signaled the potential for crises to occur in other countries; given this new information and the belief that other Latin American countries had characteristics that were broadly similar to Argentina, emerging market investors then sold their Latin American securities. ${ }^{45}$ This interpretation is similar to what some economists suggested occurred during the East Asia crisis (Radelet and Sachs, 1999). The fact that the bond spreads did

\footnotetext{
${ }^{45}$ The Economist noted the bellwether status of Argentina during this period, noting that bond prices of other South American securities moved when Argentina moved (Economist, April 29, 1893).
} 
not rise for the Latin American countries in the months preceding the crisis is consistent with a wake-up call interpretation of the Baring Crisis and similar to what has been observed during the East Asian Crisis. ${ }^{46}$

Incomplete information about the financial health and growth prospects of particular Latin American countries may have made it difficult for investors to assess risk on a country-bycountry basis prior to Argentina's default, and may have contributed to a sell off of Latin American debt. It might also help explain why a wake up call occurred. ${ }^{47}$ The fact that European investors lacked all the information they desired is well documented by the Corporations of Bondholders (CFB), which represented British lenders, and which was created, in part, to provide better information on sovereign borrowers (Mauro and Yafeh, 2003). Despite the efforts of British bondholders, the written records of this organization (the Annual Reports of the CFB) consistently reveal the frustration of bondholders in their attempts to obtain accurate and timely reports on the fiscal balance, monetary emissions, and tax collection of debtor nations during the gold standard period.

Although it would be difficult to design a definitive test of the role of asymmetric information during our sample period, we carried out some sensitivity testing that provides some additional insight into the problems of asymmetric information with respect to Latin America. We estimated a model where we explain the variation in yield spreads for emerging market borrowers using the available information on country-specific macroeconomic and financial characteristics, but excluding Latin American debtors from the sample. We find that the macroeconomic and trade variables (as well as the conflict variables) generally have a statistically significant effect in

\footnotetext{
${ }^{46}$ Sovereign credit ratings for East Asian economies by major private credit-rating agencies did not decline in the 18-month run up to the East Asian financial crisis. This has been cited as evidence that rating agencies and private creditors were asleep at the wheel prior to the outbreak of the crisis in Thailand (Goldstein, 1998).

${ }^{47}$ There is some evidence that the "wake up call" that may have occurred during the East Asian financial crisis was exacerbated by asymmetric information problems. According to Goldstein (1998, p.19),

"creditors did not have accurate information on the creditworthiness of Asian borrowers (e.g., external debt turned out to be much larger, and international reserves much smaller, than indicated by publicly available data)." Of course, for our period, the problems may have involved both inaccurate and incomplete information.
} 
the explaining the cross-sectional behavior of yield spreads for non-Latin emerging market borrowers. ${ }^{48}$ The fact that a regression model can explain non-Latin yield spreads, but not Latin American interest rates, provides some statistical evidence that asymmetric information may have played a role in the financial crisis (or alternatively that the quality of economic information on sovereign borrowers in Latin America was relatively poor). Even if such information had predictive power, it was lacking for many countries of interest in the region: several Central and South American countries, which we would have like to have included in our full panel specification, lacked adequate financial and trade data from conventional sources that were available to investors in the 1890s (such as the Investor's Monthly Manual and the Statesman's Yearbook). The paucity of data for the region made it a more challenging environment for investors to discern good risk from bad risk, and may help explain the sell off Latin American debt.

The presence of a common creditor may also help explain the large increase in Latin American interest rates following the onset of the Baring Crisis. ${ }^{49}$ Investment banks that lent to Argentina were largely concentrated in London. Harmed by the Argentine default, they may have decided to cut back on their investments in the entire Latin American region to reduce their exposure to risk of a similar variety. Since other countries in their region had trade patterns, fiscal histories, and corporate governance similar to Argentina, this may have induced UK investors to reallocate their portfolios and shift funds to other parts of the world like the British Empire or other emerging markets. Such an unwinding of positions does not necessarily proceed at a rapid pace, and may also help explain why bond spreads continued to rise more than a year after the crisis.

\footnotetext{
${ }^{48}$ For example, unlike the baseline results reported in Column 2 of Table 5, we find that the debt-torevenue ratio significantly raises yield spreads by approximately 120 basis points, interstate war raises sovereign risk by 46 basis points, and a better trade balance lowers sovereign risk at the five percent. Debt default raises yield spreads by 660 basis points and exports per capita increases sovereign risk by about 15 basis points.

${ }^{49}$ A common-creditor channel has been used to explain recent episodes of financial contagion in East Asia and Latin America (Dornbusch, Park, and Claessens, 2002).
} 
As a way to test the common creditor hypothesis, we re-estimated the empirical model in Column 2 of Table 5, adding two interaction terms to measure the effects of the Baring Crisis outside of Latin America. First, we interacted the empire indicator variable with the crisis dummy to test the hypothesis that European investors may have sold-off or reduced their holdings of Latin American securities and purchased "British-guaranteed" colonial bonds or debt in nonLatin emerging markets. Then, we interacted the non-empire emerging market variable with the crisis dummy to capture the effect of the Baring Crisis on British colonies and developing countries outside of Latin America. Although the empire interaction variable is not statistically significant, we find some evidence that yield spreads in non-Empire, non-Latin Emerging market actually declined about 42 basis points following the outbreak of the crisis. ${ }^{50}$ The falling yield spreads (and hence rising prices of non-Latin emerging market debt) provide some evidence that UK investors shifted some of their funds to non-Latin emerging markets during the early 1890 s. Overall, the empirical analysis suggests that sovereign yield spreads in Latin America significantly increased in the years following the outbreak of the Baring Crisis.

\section{Conclusion}

This paper offers quantitative evidence of the effects of the Baring Crisis on a global sample of emerging market borrowers. Using a new database of more than 15,000 bond prices collected from the Economist, we find that the Baring Crisis was largely a regional phenomenon. The average sovereign yield spread for Latin American countries in our sample increased by 844 , 759 , and 1,608 basis points in the one-year, two-year, and four-year periods after the onset of the financial crisis. On the other hand, yield spreads in non-Latin emerging markets and core countries were generally flat during the same period.

\footnotetext{
${ }^{50}$ The crisis and Latin American-crisis interaction variables are both significant at the 5-percent level of significance.
} 
We then analyzed the determinants of sovereign yield spreads between 1886 and 1896 in a panel framework to shed greater light on the regional nature of the crisis. We were particularly interested in determining whether the Latin American effect could be explained by macroeconomic fundamentals (a budget deficit ratio, a ratio of debt-to-revenue, a default indicator variable), trade indicators (trade balance, exports per capita), political variables (interstate and domestic conflict) and institutional variables (such as being on the gold standard) information available to emerging market investors in the late nineteenth century. The empirical analysis of sovereign yield spreads using fixed-effects models in a panel framework suggests several conclusions. Macroeconomic indicators such as the debt burden, the budget deficit, and the trade deficit as well as the political variables were generally not very important for pricing sovereign debt during this turbulent period. On the other hand, we find that countries that suspended debt service were charged much higher interest rates in financial markets. The results also suggest that being on the gold standard offered safe haven for borrowers that committed to this policy regime during the crisis of the 1890 s and that trading more with the UK increased country risk during the crisis.

Finally, and perhaps most importantly, the results suggest the existence of a large Latin American effect, even after controlling for both observed and unobserved differences across countries. Yield spreads were more than 200 basis points higher for Latin American countries during the crisis. Statistical and historical evidence suggests that European investors sold off or reduced their holdings of Latin American bonds. Investors re-assessed sovereign risk in Latin America and reduced their holdings of government bonds issued by countries in the region, perhaps in part due to informational problems and in part to diversify away from region-specific risk. Although it is difficult to identify a single explanation that accounts for the dramatic decline in Latin American bond prices in the early 1890s, the empirical results of this paper nevertheless document that the Baring Crisis was largely a crisis confined to Latin America; it appears to have had little effect on other emerging market borrowers. As more financial and macroeconomic data 
from the area become available, future research will undoubtedly shed more light on the regional nature of the Baring crisis. 


\section{References}

Banerjee, Anindya, Robin Lumsdaine, and James H. Stock. "Recursive and Sequential Tests of the Unit-Root and Trend-Break Hypotheses: Theory and International Evidence." Journal of Business and Economic Statistics 10, no. 3 (1992): 271-87.

Bordo, Michael, Barry Eichengreen, Daniela Klingebiel and Maria Soledad Martinez-Peria.'Is the Crisis Problem Growing More Severe?" Economic Policy 16, April (2001): 51-82.

Bordo, Michael D. and Antu P. Murshid. "Are Financial Crises Becoming Increasingly More Contagious?” In International Financial Contagion, edited by Stijn Claessens and Kristin I. Forbes (eds.), 367-403. Boston: Kluwer Academic Publishers, 2001.

Bordo, Michael and Hugh Rockoff.. "The Gold Standard as a Good Housekeeping Seal of Approval." Journal of Economic History 56, no. 2 (1996): 389-428.

Calvo, Guillermo. "Contagion in Emerging Markets: When Wall Street is a Carrier." University of Maryland Working Paper, College Park, MD, 1999.

Calvo Guillermo and Carmen Reinhart. "Capital Flows to Latin America: Is there Evidence of Contagion Effects?" In Private Capital Flows to Emerging Markets after the Mexican Crisis, edited by Guillermo Calvo, Morris Goldstein, and E. Hochreiter, 15171.Washington: Institute for International Economics, 1996.

Cameron, A. Colin, Gelbach, Jonah B., and Douglas Miller. "Robust Inference with Multi-Way Clustering." UC Davis Working Paper, Davis, CA, 2006.

della Paolera, Gerardo and Alan M. Taylor. Straining at the Anchor: The Argentine Currency Board and the Search for Macroeconomic Stability, 1880-1935. Chicago: University of Chicago Press, 2001.

Drazen, Allan. "Political Contagion in Currency Crises." NBER Working Paper 7211, Cambridge, MA, Month, 1998.

Dornbusch, Rudiger, Park, Yung Chul, and Stijn Claessens. "Contagion: How it Spreads.” World Bank Research Observer 15 no. 2 (2002): 177-97.

Eichengreen, Barry. (1999). Toward a New International Financial Architecture. Washington, D.C.: Institute for International Economics, 1999.

Eichengreen, Barry. "The Baring Crisis in a Mexican Mirror.” International Political Science Review 20, no. 3 (1999): 249-70.

Eichengreen, Barry and Jeffrey Sachs. "Exchange Rates and Economic Recovery in the 1930s." Journal of Economic History 45, no. 4 (1985): 925-46.

Eschweiler, B. "Emerging Asia: The Fallout after the FX Crisis." Asian Financial Markets. JP Morgan, Singapore, 1997.

Esteves, Rui. "Pulsacões Financeiras.” In Nova História de Portugal, edited by Joel Serrão and A.H. Oliviera Marques, 110-51. Lisbon, Portugal: Editorial Presenca, 2004. 
Ferguson, Niall and Moritz Schularick. "The Empire Effect: The Determinants of Country Risk in the First Age of Globalization, 1880-1913." This JOURNAL 66, no.2 (2006): 283-312.

Fishlow, Albert. "Conditionality and Willingness to Pay: Some Parallels from the 1890s." In The International Debt Crisis in Historical Perspective, edited by Barry Eichengreen and Peter H. Lindert, 86-105. Cambridge: MIT Press, 1989.

Flandreau, Marc and Frederic Zúmer. The Making of Global Finance. Paris: OECD, 2004.

Forbes, Kristen and Stijn Claessens. (2001). International Financial Contagion. New York: Kluwer Academic Publishers.

Forbes, Kristen and Roberto Rigobon. "No Contagion, Only Interdepence: Measuring Stock Market Co-Movements.” Journal of Finance 107, no.5 (2002): 2223-61.

Ford, Alec G. “Argentina and the Baring Crisis of 1890.” Oxford Economic Papers 8, no. 2 (1956): 127-50.

Ford, Alec.G. The Gold Standard, 1880-1914: Britain and Argentina. Oxford: Clarendon Press, 1962.

Glick, Reuven and Andrew K. Rose. "Contagion and Trade: Why Are Currency Crises Regional?” Journal of International Money and Finance 18, no.4 (1999): 603-17.

Goldstein, Morris. The Asian Financial Crisis. Washington, D.C.: Institute for International Economics, 1998.

Hahm, Joon-Ho and Frederic S. Mishkin. "The Korean Financial Crisis: An Asymmetric Information Perspective.” Emerging Markets Review 1 (2000):21-52.

International Monetary Fund. World Economic Outlook. Washington, D.C.: IMF, 1998.

Kaminsky, Graciela and Carmen Reinhart. "Financial Crises in Asia and Latin America: Then and Now." American Economic Review 88, no.2 (1998): 444-448.

Kaminsky, Graciela, Reinhart, Carmen, and Carlos A. Vegh. "The Unholy Trinity of Financial Contagion." Journal of Economic Perspectives 17, no.4 (2003):51-74.

Kindleberger, Charles Poor. "International Propagation of Financial Crises: The Experience of 1888-1893." In International Capital Movements, Debt and Monetary System, edited by Wolfram Engels, Armin Gutowski, and Henry C. Wallich, 217-34. Mainz: Hase \& Koehler, 1984.

Maddison, Angus. The World Economy. Historical Statistics. Paris: OECD, 2003.

Marichal, Carlos. A Century of Debt Crises in Latin America. Princeton: Princeton University Press, 1989.

Mauro, Paolo, Nathan Sussman, and Yishay Yafeh. "Emerging Market Spreads: Then Versus Now." Quarterly Journal of Economics 117 no.2 (2002): 695-733. 
Mauro, Paolo and Yishay Yafeh. "The Corporation of Foreign Bondholders." IMF Working Paper 03/107, Washington, DC, 2003.

Meissner, Christopher M. "New World Order: Explaining the International Diffusion of the Gold Standard, 1870-1913.” Journal of International Economics 66, no.2 (2005): 385-406.

McLean, Ian. "Recovery from Depression: Australia in an Argentine Mirror 1895-1913." Australian Economic History Review 46, no. 3 (2006):215-41.

Obstfeld, M., and A. M. Taylor. "Global Capital Markets.” In Globalization in Historical Perspective, edited by Michael. D. Bordo, Alan M. Taylor and Jeffrey. G. Williamson, 121-83. Chicago: University of Chicago Press, 2003.

Prados de la Escosura, Leandro. "International Comparisons of Real Product, 1820-1990: An Alternative Dataset." Explorations in Economic History 37, no.1 (2000):1-41.

Radelet, Steven and Jeffrey Sachs. "The East Asian Financial Crisis: Diagnosis, Remedies, Prospects." Brookings Papers on Economic Activity no.1 (1998): 1-74.

Stateman's Yearbook: Statistical and Historical Annual of the States of the World. London: Macmillan and Company, Various Years.

Suter, Christian. Debt Cycles in the World Economy: Foreign Loans, Financial Crises, and Debt Settlements, 1820-1990. Boulder, CO: Westview, 1992.

Taylor, Alan M. "Capital Accumulation," In A New Economic History of Argentina, edited by in Gerardo Della Paolera and Alan M. Taylor, 170-96. Cambridge: Cambridge University Press, 2003

Triner, Gail D. and Kirsten Wandschneider. "International Capital and the Brazilian Encilhamento, 1889-1892: An Early Example of Contagion among Emerging Markets." Financial History Review 12, no.2 (2005): 199-225.

Williams, John H. Argentine International Trade under Inconvertible Paper Currency, 1880-1900. Cambridge: Harvard University Press, 1920. 
Table 1. Central and South American Events Reported in the Investor's Monthly Manual

\begin{tabular}{|c|c|}
\hline March 26, 1890 & $\begin{array}{l}\text { Argentine Government announces its resolve to meet the economic crisis by } \\
\text { immediately adopting energetic measures, some of which they specify. }\end{array}$ \\
\hline April 2, 1890 & $\begin{array}{l}\text { Registration of the Peruvian Corporation, formed to carry out conversion of } \\
\text { debt. }\end{array}$ \\
\hline April 16, 1890 & $\begin{array}{l}\text { Resignation of Argentine Ministry, and announcement of project purchase of } \\
\text { Western Railway of Buenos Ayres by an Anglo-French syndicate. }\end{array}$ \\
\hline May 14,1890 & $\begin{array}{l}\text { Expected withdrawal of gold for the Argentine Republic. Mexican Senate } \\
\text { passes a bill for the funding of the railroad debt. }\end{array}$ \\
\hline May 28,1890 & $\begin{array}{l}\text { Uruguayan Finance Committee recommends the government to issue a new } \\
\text { loan in connection with the budget deficit. }\end{array}$ \\
\hline June 11,1890 & Resignation of the Argentine Finance Minister, Signor Uriburu. \\
\hline July 2,1890 & $\begin{array}{l}\text { Negotiations for loan of } 5,000,000 \text { pounds to Argentina, which ultimately } \\
\text { prove abortive. Argentine National Bank suspends interim dividend. }\end{array}$ \\
\hline July 9,1890 & Financial crisis in Uruguay. \\
\hline July 23,1890 & $\begin{array}{l}\text { Revolt in Buenos Ayres, with three or four days' fighting. Fighting in Central } \\
\text { America and San Salvador. }\end{array}$ \\
\hline July 30,1890 & The Argentine insurrection results in a nominal victory for the government. \\
\hline August 6, 1890 & $\begin{array}{l}\text { President Celman of the Argentine Republic, yielding at last to public feeling, } \\
\text { resigns, and the Ministry is changed. }\end{array}$ \\
\hline August 13,1890 & Directors of Argentine National Bank resign \\
\hline August 27,1890 & Brazilian decree issued practically establishing a system of Cedula issues. \\
\hline September 3, 1890 & $\begin{array}{l}\text { Proposal in Argentine Congress to suspend payments on Cedulas for two } \\
\text { years rejected. Mexican loan, } 8,000,000 \text { pounds, for redemption of railway } \\
\text { subsidies. }\end{array}$ \\
\hline September 10,1890 & $\begin{array}{l}\text { New Argentine Railway concessions annulled-Finance Minister's message } \\
\text { refers to entanglement of Government in monetary affairs-and to insolvency } \\
\text { in Buenos Ayres. }\end{array}$ \\
\hline September 17,1890 & $\begin{array}{l}\text { Dr. Plaza appointed in Argentina to visit Europe on a financial mission, } \\
\text { principally to arrange a } 4,000,000 \text { pound loan. }\end{array}$ \\
\hline September 24,1890 & Argentine Federal government proposes to assume provincial liabilities. \\
\hline October 29,1890 & Issue of Brazilian Decree rendering import duties payable in gold. \\
\hline November 19,1890 & $\begin{array}{l}\text { Fall of Barings announced simultaneously with "Guarantee" scheme of } \\
\text { assistance. Committee formed to inquire and suggest as to Argentine affairs. }\end{array}$ \\
\hline November 26,1890 & Chilian government refuses proposed terms of settlement of Dreyfus claim. \\
\hline December 3,1890 & Argentine Committee reports its conclusions. \\
\hline December 10,1890 & German delegate to Argentine Conference issues his report. \\
\hline December 17,1890 & A scheme is propounded for the conversion of the Argentine Cedula issues. \\
\hline December 30,1890 & $\begin{array}{l}\text { Dr. Plaza intimates the willingness of the [Argentine] government to accept } \\
\text { the proposals of the Rothschild Committee subject to minor modifications. } \\
\text { Cordova and Entre Rios announce that interest payments on their coupons are } \\
\text { "postponed pending negotiations." }\end{array}$ \\
\hline
\end{tabular}


Table 2. Average Changes in Latin American Yield Spreads, 1890-1894

\begin{tabular}{|c|c|c|c|}
\hline Country & July 1890-June 1891 & July 1890-June 1892 & Jul 1890-June 1894 \\
\hline Argentina & 675.26 & 682.53 & 689.44 \\
\hline Brazil & 44.58 & 227.05 & 130.06 \\
\hline Chile & 90.06 & 44.3 & 73.44 \\
\hline Colombia & 1263.79 & 875.23 & 1871.72 \\
\hline Costa Rica & 139.54 & 190.1 & 332.3 \\
\hline Guatemala & 291.69 & 168.52 & 972.53 \\
\hline Honduras & 7136.3 & 5357.85 & 11912.38 \\
\hline Mexico & 44.77 & 75.83 & 389.39 \\
\hline Nicaragua $\dagger$ & 33.84 & 96.67 & 159.14 \\
\hline Paraguay & 113.35 & 401.87 & 908.78 \\
\hline Portugal & 162.98 & 723.04 & 836.51 \\
\hline Spain & -0.22 & 61.5 & 83.19 \\
\hline Uruguay & 202.48 & NA & NA \\
\hline Venezuela & 94.07 & 224.15 & 252.39 \\
\hline $\begin{array}{l}\text { Group Average } \\
\text { (without Spain and Portugal) }\end{array}$ & 844.14 & 758.55 & 1608.33 \\
\hline $\begin{array}{l}\text { Group Average } \\
\text { (with Spain and Portugal) }\end{array}$ & 735.18 & 702.2 & 1431.64 \\
\hline $\begin{array}{l}\text { Group Average } \\
\text { (without Argentina) }\end{array}$ & 739.79 & 703.84 & 1493.49 \\
\hline
\end{tabular}


Table 3. Average Changes in Emerging Market Yield Spreads, 1890-1894

Country

Austria

British Guiana

Canada

Cape of Good Hope (South

Africa)

Egypt

Greece

India

Italy

Jamaica

Japan

Natal

New South Wales

New Zealand

Norway

Queensland

Russia

South Australia

Sweden

Tasmania

Ottoman Empire (Turkey )

Victoria

Western Australia

Group Average

Group Average (without Greece)
July 1890-June

1891

$-11.14$

7.68

0.84

$-2.6$

$-9.82$

32.22

3.94

$-7.29$

$-10.52$

$-12.62$

11.88

$-6.56$

$-4.7$

5.94

$-2.75$

$-2.88$

$-2.83$

$-2.75$

$-2.68$

3.05

3.89

$-10.37$

$-0.91$

$-2.49$
July 1890-June

1892

$-3.87$

22.5

0.71

4.67

$-6.83$

92.29

3.07

3.64

$-7.13$

0.71

23.04

0.71

2.57

9.99

8.4

11.96

4.44

$-3.02$

0.71

5.47

7.86

$-6.83$

7.96

3.94
July 1890-June

1894

$-10.12$

37.25

0.5

3.74

$-19.07$

1071.07

4.53

105.77

$-7.76$

7.62

22.23

10.65

11.43

$-16.5$

15.16

11.43

7.62

2.95

7.86

$-10.7$

56.87

8.58 
Table 4. Average Changes in Core Market Yield Spreads, 1890-1894

\begin{tabular}{lccc}
$\begin{array}{l}\text { Country } \\
\text { Belgium }\end{array}$ & July 1890-June 1891 & July 1890-June 1892 & July 1892-June 1894 \\
\hline France & -19.86 & -9.37 & -2.46 \\
\hline Germany & -20.74 & -28.05 & -22.68 \\
\hline Netherlands & -10.29 & -6.69 & 3.89 \\
\hline US & 1.25 & 12.58 & -20.12 \\
\hline Group Average & 4.37 & 17.39 & 33.29 \\
\hline
\end{tabular}

Either the percentage change in prices or the increase or decrease in yield spreads (measured in basis points) is reported. 
Table 5: Analysis of Yield Spreads and the Baring

Crisis, 1886-1896

Emerging Market Control

\begin{tabular}{cc}
$\frac{\text { Fixed }}{\text { Effects }}$ & Fixed \\
\hline 1.808 & $\frac{\text { Effects }}{2.494}$ \\
$(1.37)$ & $(1.54)$ \\
$386.685 * *$ & $347.820^{* *}$ \\
$(174.09)$ & $(167.73)$ \\
-29.908 & -56.99 \\
$(30.37)$ & $(44.24)$ \\
-7.579 & 0.098 \\
$(13.87)$ & $(12.80)$ \\
12.416 & -7.051 \\
$(24.05)$ & $(24.96)$ \\
3.03 & $9.215 *$ \\
$(4.84)$ & $(5.41)$
\end{tabular}

Empire

Gold

$\begin{array}{cc}-79.165 & -48.105 \\ (76.69) & (92.30) \\ & -74.987 * * * \\ & (28.25) \\ 8.772 & -16.915 \\ (40.20) & (31.52) \\ -3.462 & -45.733 \\ (35.55) & (36.59) \\ -126.495 & 121.171 \\ (344.71) & (365.01)\end{array}$

Latin

11.101

(24.63)

$213.690 * *$

(107.36)

Empire* Crisis

$-2.028$

(23.54)

UK Trade Share

$-2.639$

(2.26)

Crisis*UK Trade Share

1.05

(0.79)

Latin*UK Trade Share

9.893

(7.73)

Observations

375

368

R-squared

0.84

0.86

Robust standard errors in parentheses

* significant at $10 \% ; * *$ significant at $5 \%$; *** significant at $1 \%$ 
Figure 1

Yield Spreads for Argentina, Brazil, and Chile

1886-1895

(Basis Points)

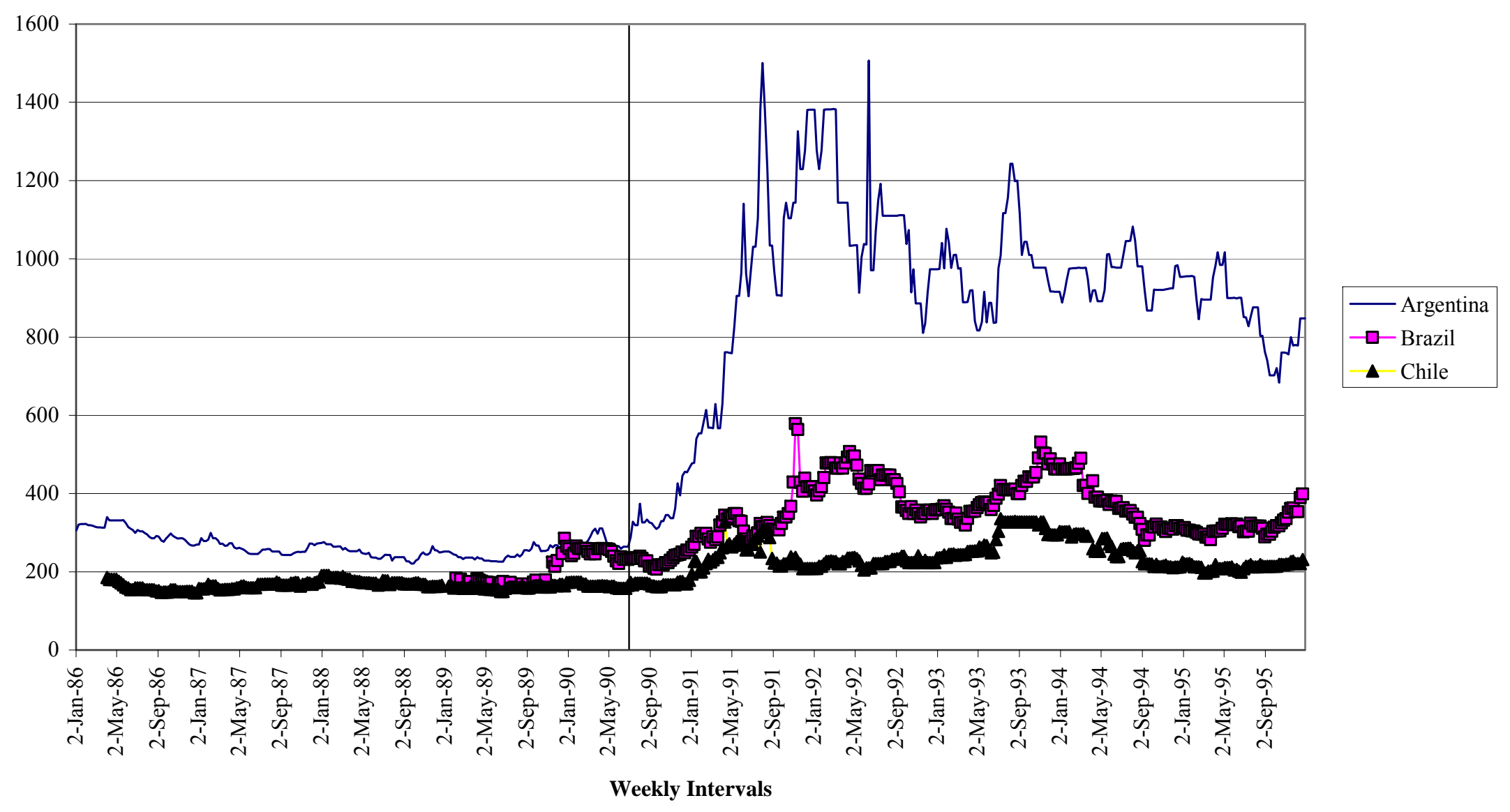


Figure 2

Yield Spreads for Colombia, Nicaragua, and Honduras

1886-1895

(Basis Points)

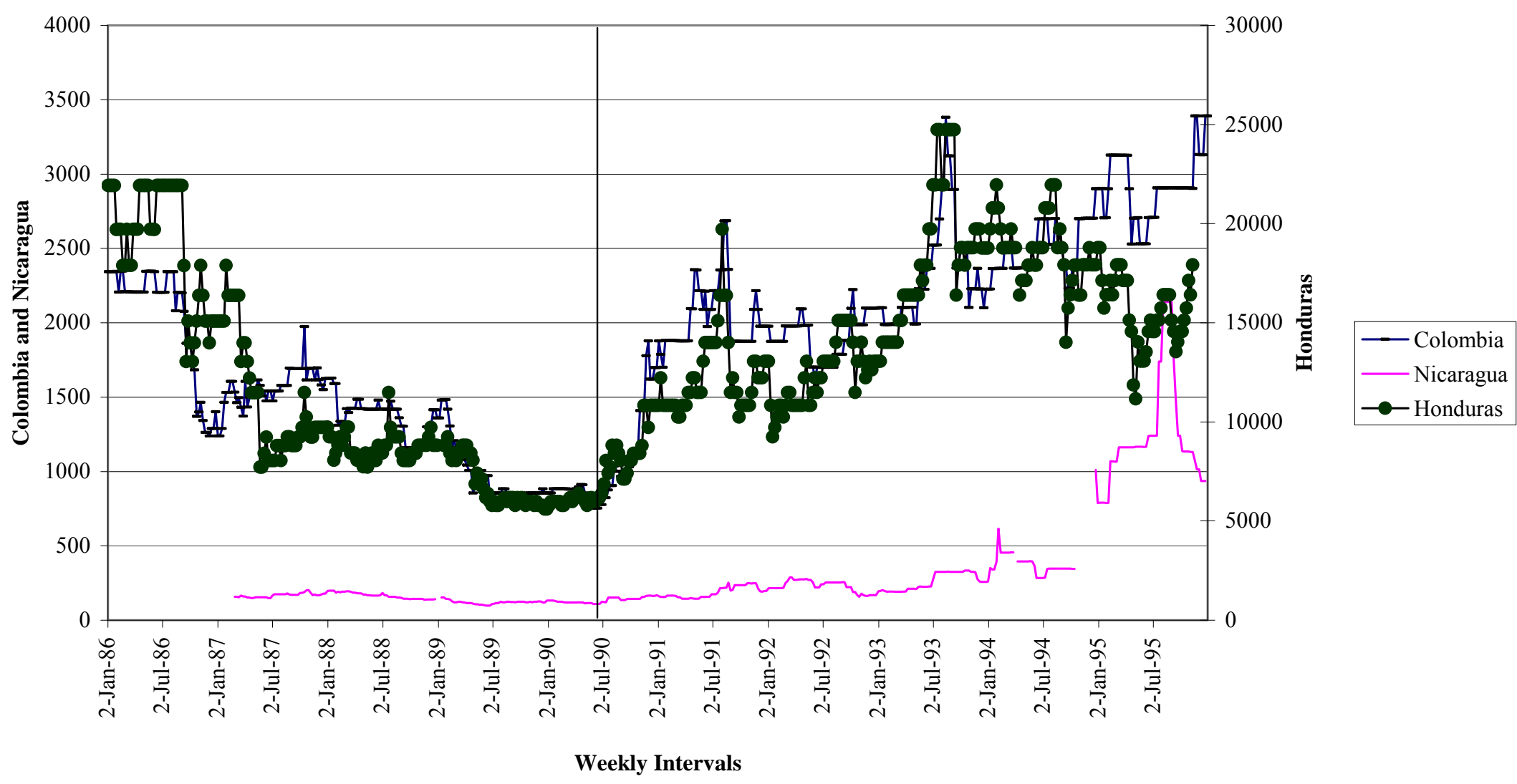


Figure 3

Yield Spreads for Costa Rica and Guatemala

1886-1895

(Basis Points)

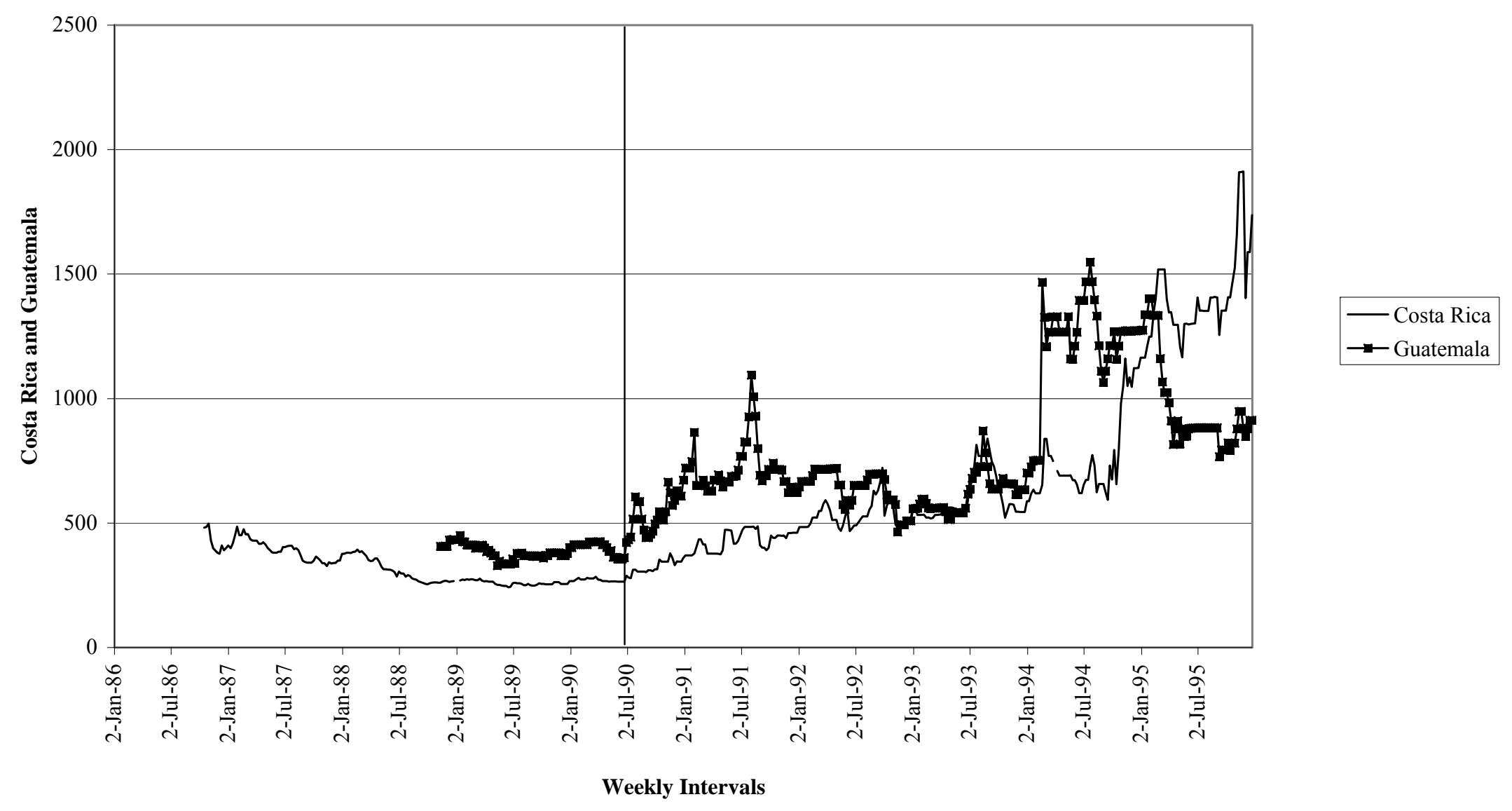


Figure 4

Yield Spreads for Mexico and Paraguay

1886-1895

(Basis Points)

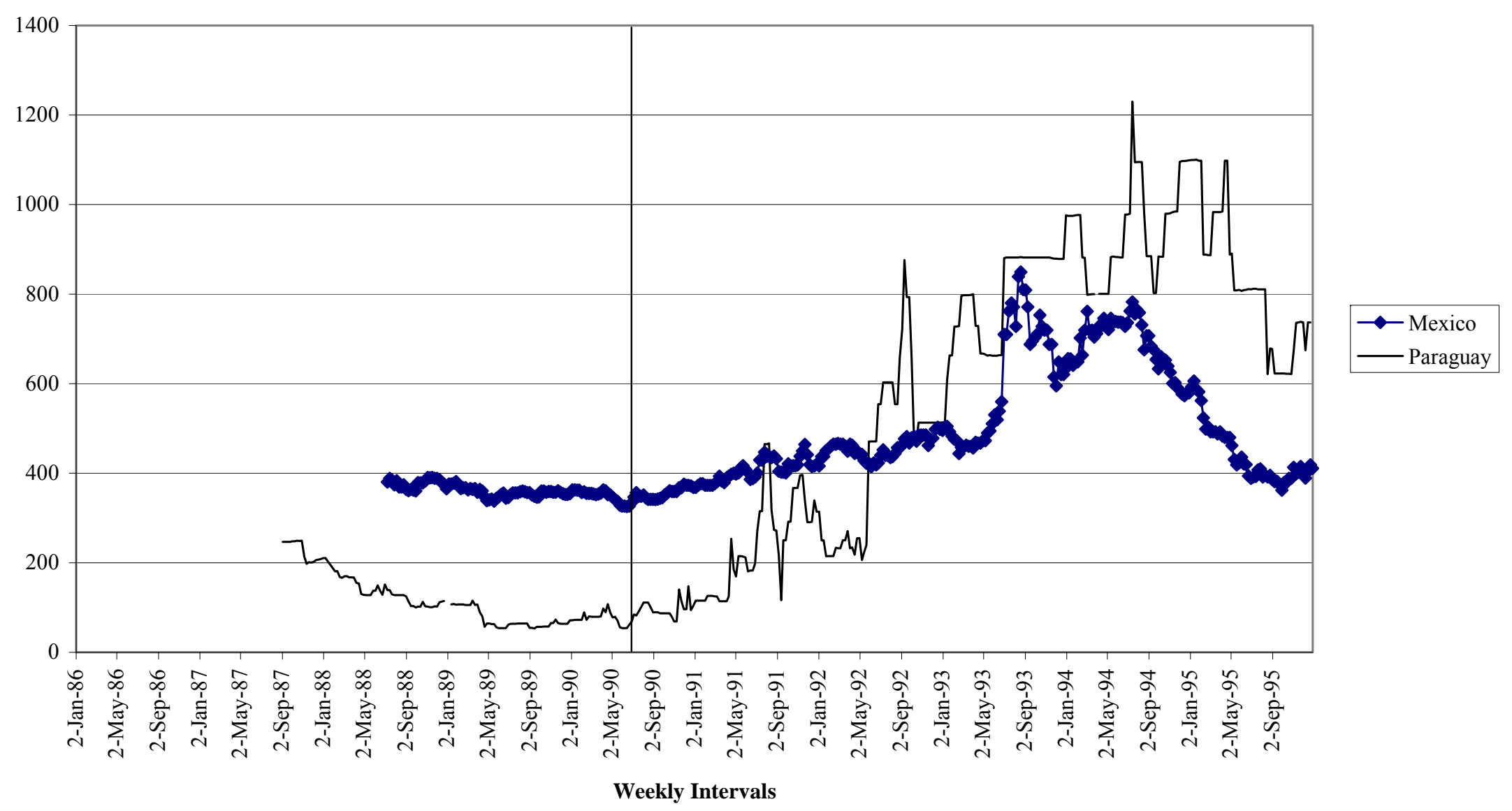


Figure 5

Yield Spreads for Uruguay and Venezuela

1886-1895

(Basis Points)

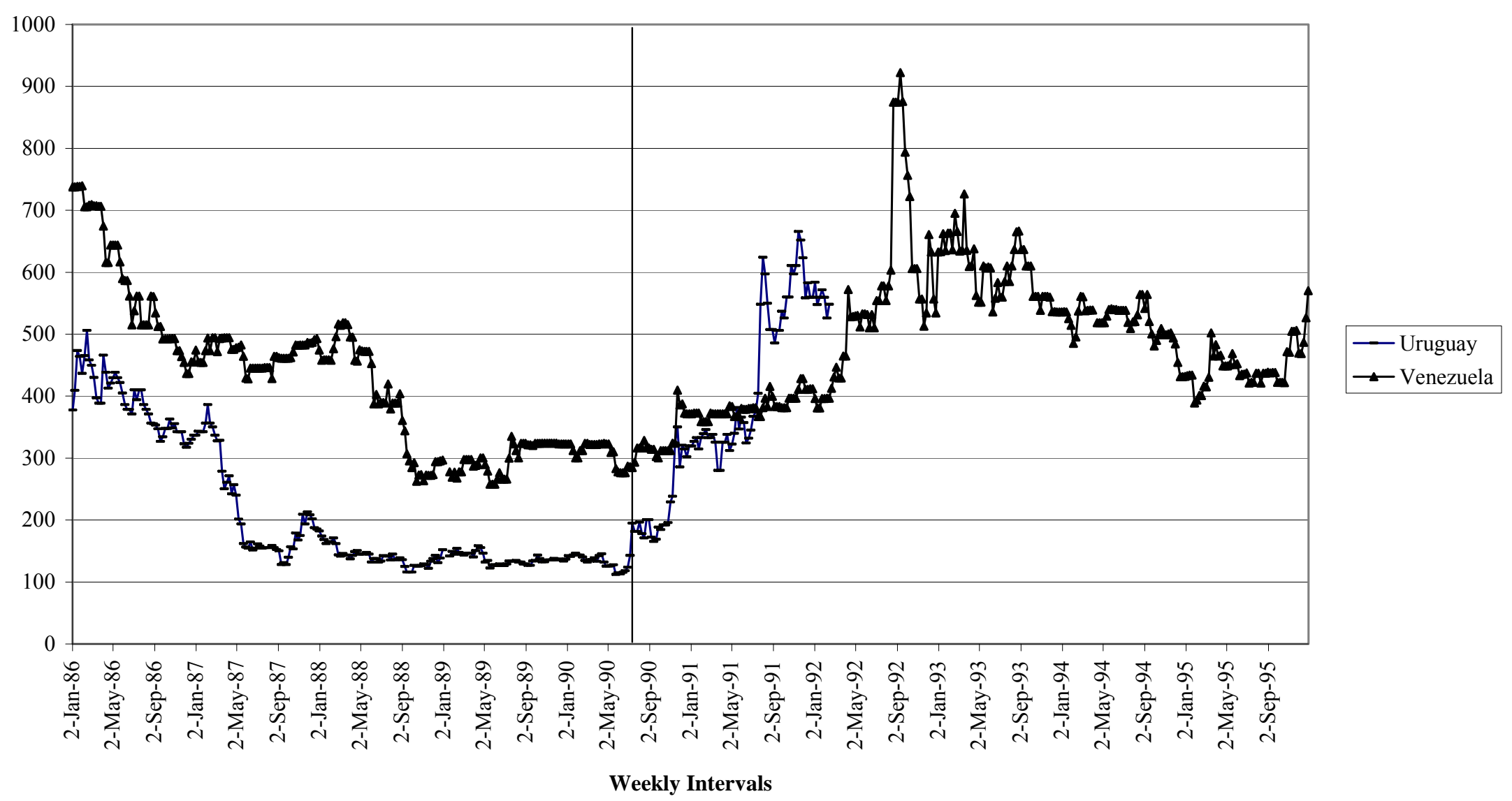


Figure 6

Bond Yield Indices 1887-1895

(Basis Points)

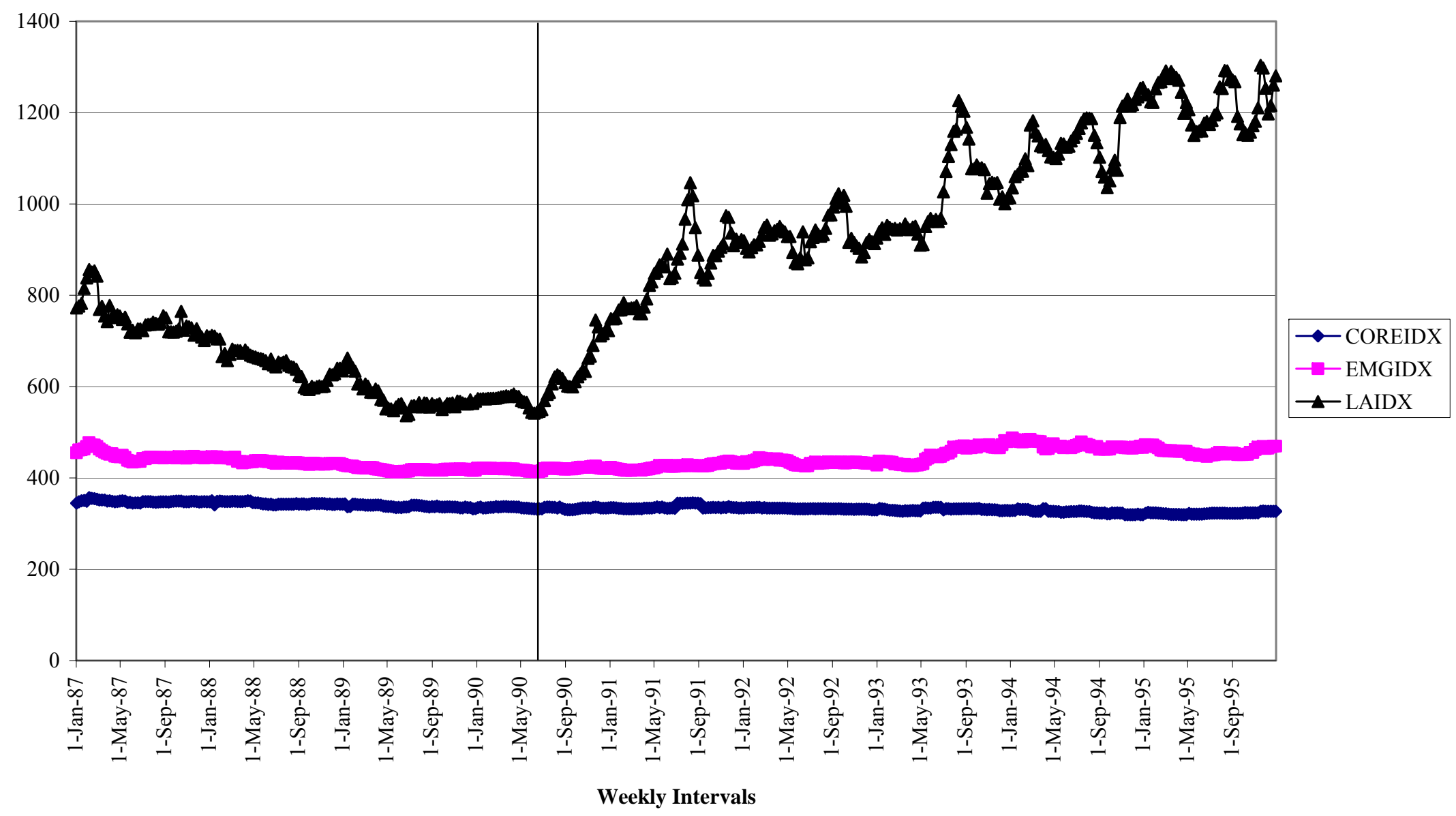




\section{Data Appendix}

\section{Core Countries}

Belgium (1874), 3\%, perpetuity bonds

French Rentes, 3\%, perpetuity bonds

Netherlands, $2.5 \%$, perpetuity bonds.

Prussian Consols, 3\%, perpetuity bonds

USA 4\%, due 1907

\section{Latin American Countries}

Argentina (1884), 5\%, final redemption 1921

Brazil (1888), 4.5\%, redemption by sinking-fund of 1 percent per annum

Chile (1885), $4.5 \%$, redeemable by a sinking-fund of $1 / 2$ percent per year

Colombia (1873), $4.75 \%$, in default

Costa Rica A, 5\%, sinking-fund commences in 1898 to begin redeeming the bonds

Guatemala, $4 \%$

Honduras (1867), 10\%, in default

Mexico (1888), 6\%, irredeemable after 1892

Nicaragua (1886), 4\%-begin 6\% December 29, 1894

Paraguay (1886), 1.5\%, redeemable by sinking-fund beginning in 1896

Portugal, 3\%, change to $1 \%$ in November, 1895

Spain, $4 \%$, perpetuity bonds

Uruguay Consol, $3 \%$

Venezuela (1859), 3\%, redeemable by semi-annual sinking-fund

\section{Non-Latin Emerging Markets}

Austrian Gold Bonds (consols), 4\%, perpetuity bonds

British Guiana, 4\%, 1935

Canada, 4\%, due 1904-08

Cape of Good Hope (1881), 4\%, final redemption in 1922

Greece (1881), 5\%, final redemption in 1921

India, 3\%, due October 5, 1948

Italy (ex 25f), 5\%, perpetuity bonds

Jamaica, 4\%, Inscribed, 1934

Japan (1873), 7\%, final redemption in 1898

New South Wales, 4\%, due 1903-5-8-9-10

New Zealand Inscribed Stock, 4\%, final redemption in 1929

Norway, 3\%, final redemption in 1965

Queensland, 4\%, due 1913

Russia (1822), 5\%, perpetuity bonds

South Australia, 4\%, due 1929

Sweden (1880), 4\%, final redemption in 1930

Tasmania, 4\%, due July 8, 1908

Turkey (1854, Egyptian Tribute), 5\%, final redemption in 1927

Victoria, 4.5\%, due 1904

Western Australia, 4\%, due 1927 
Appendix Table 1. The Baring Crisis and Latin American Bond Returns, 1887-1895

\section{$\underline{\text { Panel A }}$}

(Dependent Variable: Bond Return for Latin American Country i, excluding Argentina)

\begin{tabular}{|c|c|c|c|c|}
\hline $\begin{array}{l}\text { Independent } \\
\text { Variable }\end{array}$ & $\begin{array}{c}(1) \\
\text { Pooled } \\
\text { OLS }\end{array}$ & $\begin{array}{c}(2) \\
\text { Pooled } \\
\text { OLS }\end{array}$ & $\begin{array}{c}(3) \\
\text { Pooled } \\
\text { OLS }\end{array}$ & $\begin{array}{c}(4) \\
\text { Pooled } \\
\text { OLS }\end{array}$ \\
\hline Constant & $\begin{array}{c}-.119 * * \\
(.056)\end{array}$ & $\begin{array}{l}-.054 \\
(.059)\end{array}$ & $\begin{array}{l}-.026 \\
(.061)\end{array}$ & $\begin{array}{c}.061 \\
(.065)\end{array}$ \\
\hline $\begin{array}{l}\text { Emerging } \\
\text { Market } \\
\text { Control }\end{array}$ & $\begin{array}{c}1.881 * * * \\
(.172)\end{array}$ & $1.854 * * *$ & $\begin{array}{c}1.856^{* * *} \\
(.172)\end{array}$ & $\begin{array}{c}1.835 * * * \\
(.171)\end{array}$ \\
\hline Baring9091 & & $\begin{array}{c}-.538 * * * \\
(.177)\end{array}$ & & \\
\hline Baring9092 & & & $\begin{array}{c}-.391 * * * \\
(.146) \\
\end{array}$ & \\
\hline Baring9094 & & & & $\begin{array}{c}-392 * * * \\
(.115)\end{array}$ \\
\hline R-squared & 0.028 & 0.030 & 0.030 & 0.030 \\
\hline Obs. & 4728 & 4728 & 4728 & 4728 \\
\hline
\end{tabular}

\section{Panel B}

(Dependent Variable Bond Return for Latin American Country i, excluding Argentina, Portugal, and Spain, and Countries that Initially Defaulted on their Debts Between 1890 and 1895)

\begin{tabular}{|l|c|c|c|c|}
\hline $\begin{array}{l}\text { Independent } \\
\text { Variable }\end{array}$ & $\begin{array}{c}(1) \\
\text { Pooled } \\
\text { OLS }\end{array}$ & $\begin{array}{c}(2) \\
\text { Pooled } \\
\text { OLS }\end{array}$ & $\begin{array}{c}(3) \\
\text { Pooled } \\
\text { OLS }\end{array}$ & $\begin{array}{c}(4) \\
\text { Pooled } \\
\text { OLS }\end{array}$ \\
\hline Constant & $\begin{array}{c}-.068 \\
(.063)\end{array}$ & $\begin{array}{c}-.005 \\
(.067)\end{array}$ & $\begin{array}{c}.00005 \\
(.069)\end{array}$ & $\begin{array}{c}.064 \\
(.079)\end{array}$ \\
\hline $\begin{array}{l}\text { Emerging } \\
\text { Market }\end{array}$ & $\begin{array}{c}1.705^{* * *} \\
(.218)\end{array}$ & $\begin{array}{c}1.680^{* * *} \\
(.218)\end{array}$ & $\begin{array}{c}1.689 * * * \\
(.218)\end{array}$ & $\begin{array}{c}1.674 * * * \\
(.217)\end{array}$ \\
\hline Baring9091 & & $\begin{array}{c}-.526^{* * *} \\
(197)\end{array}$ & & \\
\hline Baring9092 & & & $-.285^{*}$ & $(.160)$ \\
\hline Baring9094 & & & & $\begin{array}{c}-.275^{* * *} \\
(.126)\end{array}$ \\
\hline R-squared & 0.030 & 0.030 & 0.030 & 0.030 \\
\hline Obs. & 3054 & 3054 & 3054 & 3054 \\
\hline
\end{tabular}




\section{$\underline{\text { Notes for Appendix Table A }}$}

Panel corrected standard errors (PCSE) are in parentheses. The regressions were estimated for the period January 1887 through December 1895 using weekly bond price data collected from the Economist. ${ }^{*}$ denotes significance at the 10 -percent level. ${ }^{*}$ denotes significance at the 5 -percent level. ***denotes significance at the 1-percent level.

The following model is employed to estimate the effect of the Baring Crisis on weekly Latin American bond returns:

(1) $\operatorname{LATINBRET}_{\mathrm{it}}=\alpha_{\mathrm{i}}+\beta_{1}$ EMGRETt $+\beta_{2}$ CRISIS $_{\mathrm{t}}+\varepsilon_{\mathrm{it}}$,

where $L A T I N B R E T_{\mathrm{it}}$ is the return on a "representative" sovereign bond for Latin American country $i$ at time t. The return for Latin American country i's representative bond is measured as the first difference of the natural logarithm of the price at time $t . \alpha_{\mathrm{i}}$ is a time-invariant constant for each country. EMGRET $T_{\mathrm{t}}$ is the emerging market control, which is computed as the first difference of the natural logarithm of the (unweighted) average price of the 14 non-Latin American emerging market bonds in our sample. We include CRISIS $_{\mathrm{t}}$ to measure the differential impact of the Baring Crisis on Latin American bond returns at three different time horizons: 1890-91, 189092, and 1890-94. These indicator variables allow us to test whether bond returns in Latin America were significantly lower than bond returns for core-country securities one-year, two-years, and four-years after the onset of the financial crisis. 